\title{
The Language of the Sea: Flags and Identities in Early Modern Dutch Marine Painting
}

\section{DAVID ONNEKINK}

David Onnekink (1971) is Assistant Professor in early modern international relations at the Department of History and Art History of Utrecht University. He was a fellow at Het Scheepvaartmuseum (Amsterdam, 2016-2017) and the Netherlands Institute for Advanced Studies (Amsterdam, 2016) where research for this article was conducted. In March 2018 he delivered the bi-annual Dwight D. Eisenhower endowed lecture on War and Peace at Kansas State University on the theme of this article. In July 2019 his latest book, The Dutch in the Early Modern World. A History of a Global Power (with Gijs Rommelse) was published with Cambridge University Press. He is currently working on a project on the history of global mission, with a particular interest in missionary cartography.

\begin{abstract}
This article investigates the convergence between early modern Dutch marine painting and contemporaneous political identities and diplomatic conventions. It uses the depiction of flags on paintings of naval battles as a lens to query perceptions of national and regional identity as well as international hierarchy. It first introduces the phenomenon of flags on marine paintings and shows how these depictions are not random or ornamental but exhibit patterns and motifs. It then builds on this observation to pursue two further arguments. Firstly, it argues that the configuration of flags on paintings of naval battles resonates with the multi-layered body politic of the Dutch Republic, representing not just the States-General and the Dutch state, but also the towns, provinces, and admiralties as distinct units. Secondly, the positioning of the flags on paintings show an awareness of debates about international hierarchy and thus a convergence with diplomatic practice. The overall purpose of the article is to underscore the value of flag research, and more generally of crossover research between the disciplines of New Diplomatic History, art history, and vexillology.
\end{abstract}

Keywords: naval battles, paintings, vexillology, political identities, diplomacy

DOI 10.18352/emlc.126 - URL: http://www.emlc-journal.org

Publisher: Stichting EMLC, supported by Utrecht University Library Open Access Journals | The Netherlands Copyright: The Author(s). This work is licensed under a Creative Commons Attribution-NonCommercial 4.0 International License. 


\section{The Language of the Sea: Flags and Identities in Early Modern Dutch Marine Painting}

\section{DAVID ONNEKINK}

In his Skirmish between Amsterdam and English ships (1614), Hendrik Vroom depicted a scene in which several men-of-war are locked in battle (fig. 1). It is a dynamic painting, with rolling waves, firing cannons, and taut sails accentuating speed and wind. The colours grey and dark-blue dominate the painting, so that the bright flags stand out conspicuously: the red blood flag, the Dutch tricolour, the Stuart royal standard, the St. George's Cross, and the red-and-white Stuart naval ensign. Indeed, the flags are the most striking features of the painting altogether. ${ }^{1}$

Maritime art took off in the last decade of the sixteenth century with the work of the Haarlem artist Hendrick Cornelisz. Vroom (1566-1640). ${ }^{2}$ Vroom's success attracted new artists to the scene, thus widening the scope. ${ }^{3}$ While often bought by private individuals, maritime paintings were also commissioned by city councils and admiralties, and had political connotations, glorifying the Dutch Republic and its constituent members. ${ }^{4}$ Margarita Russell has suggested that it was no coincidence that the rise of the Dutch seaborne empire coincided almost exactly with the emergence of marine painting in the 1580 os hence her reference to Vroom as the 'painter to the seaborne empire'. 5 The subgenre of naval battle scenes also became popular, outstripping the number of paintings of land

1 Hendrick Cornelisz. Vroom, Schermutseling tussen Amsterdamse en Engelse oorlogsschepen, 20 april 1605 (ca. 1614), Amsterdam, Het Scheepvaartmuseum, A.0oo2; Daalder, 'Schermutseling in het Kanaal', 22-23. This article was written thanks to a Dr. Ernst Crone Fellowship of the Scheepvaartmuseum in Amsterdam and a fellowship of the Netherlands Institute for Advanced Studies (NIAS). I also owe a debt to the History Department of Kansas State University for inviting me to deliver the endowed Dwight D. Eisenhower Lecture on War and Peace in March 2018 on this subject. I thank Remmelt Daalder, Michiel van Groesen, Gijs Rommelse, the members of the Early Modern History seminar of the Philipps-Universität Marburg, and the members of the History Department of Kansas State University for their critical comments. I would also like to thank the editors of EMLC, David van der Linden, Judith Noorman and Jorris Oddens, and the two anonymous referees for their extensive and useful feedback. Thanks also to Kate Delaney for editing the text. Any mistake is obviously mine.

2 Cockett, Early sea painters, 13; Taylor, Marine painting, 21; Russell, Visions of the sea, deals with Vroom's career.

3 Russel, Visions of the Sea, 177.

4 Goedde, 'Seafaring', 21.

5 Russell, Visions of the sea, 141. 


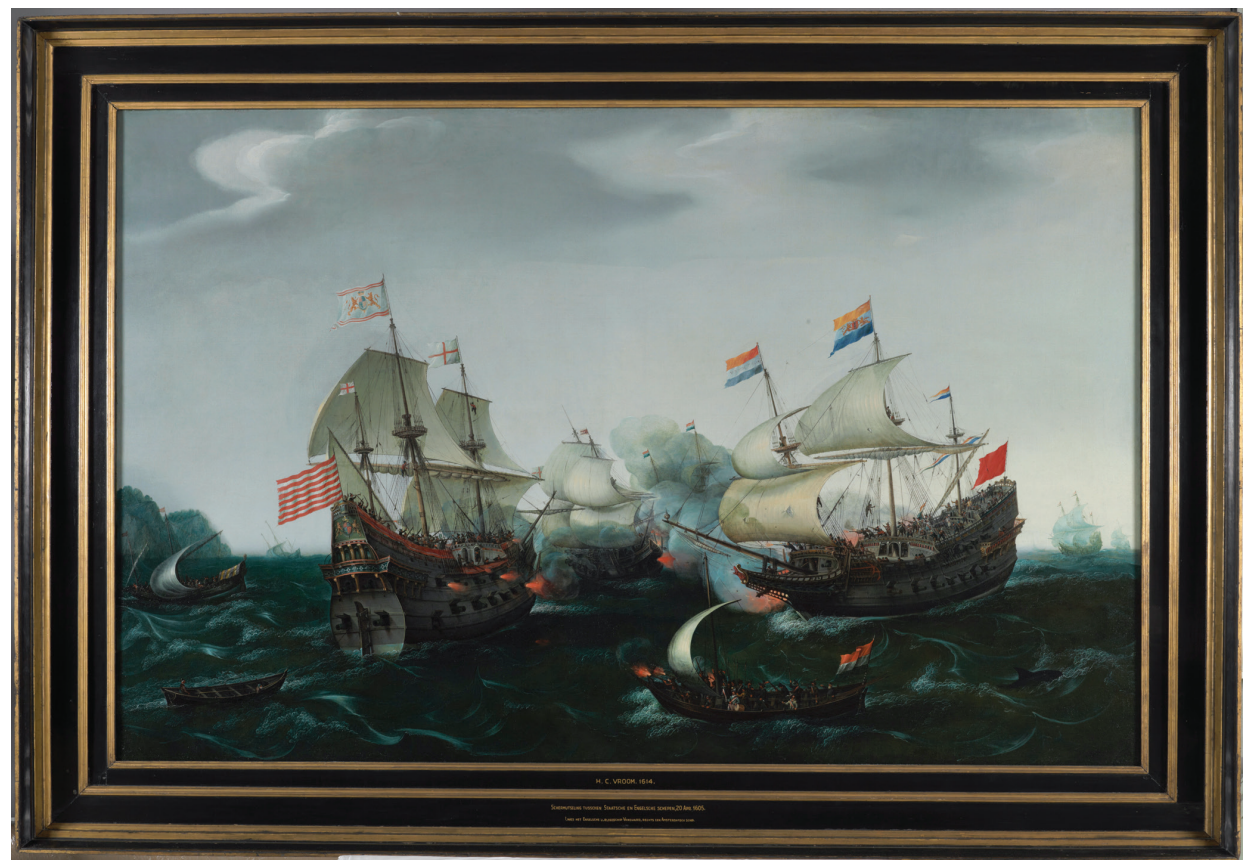

Fig. 1 Hendrick Cornelisz. Vroom, Skirmish between Amsterdam and English ships, 20 April 1605 (1614), oil on canvas, $151,5 \times 238 \mathrm{~cm}$, Amsterdam, Het Scheepvaartmuseum, A.ooo2.

battles. ${ }^{6}$ Arguably this subgenre reached its zenith during the third quarter of the seventeenth century during the Anglo-Dutch Wars, with Willem van de Velde the Elder (1611-1693) and his son, Willem the Younger (1633-1707), leading the pack of marine artists. The former was also commissioned by the admiralty to sketch images of naval battles and even travelled with the fleet to witness live clashes. ${ }^{7}$

Art historians have paid plenty of attention to seascapes, but have often bypassed the subgenre of naval battle scenes. ${ }^{8}$ Even so, the methodological debate amongst art historians such as Lawrence O. Goedde, Svetlana Alpers, and Eddy de Jongh concerning the extent to which depictions have symbolic meaning or can be deemed realistic remains relevant. ${ }^{9}$ Undoubtedly, paintings of naval battles were deeply symbolic and probably ideological. At the same time, it is well known that many of these paintings offered a surprisingly realistic representation of actual battles and of the composition of the ships involved. Naval

6 Goedde, 'Seafaring', 23.

7 Daalder, Van de Velde en zoon, 85.

8 By way of example: in Cockett, Early sea painters, only a tiny minority of the paintings discussed shows a battle scene. Sigmond and Kloek, Hollands Glorie, discusses sea battles, but is a popular rather than scholarly publication.

9 De Jongh, Questions of meaning, is a key publication that deals with this issue. See also Goede, 'Het zeestuk als historie en metafoor'; Goedde, Tempest and shipwreck, xvi-xvii. 
historians have sometimes regarded these paintings as true-to-life descriptions of actual events or ships. ${ }^{10} \mathrm{~A}$ useful balance is struck by Goedde, who has stated that such paintings are an 'imaginative re-creation of the battle'. In his view these paintings are both 'history and metaphor'. ${ }^{11}$

A striking feature of many of these paintings are the flags. Despite their ubiquity the subject has received no systematic attention, whereas it stands to reason that flags play a key role in understanding the ideological significance of paintings of naval battles. Indeed, 'the flags used by ships are the heraldry and the traditional language of the sea', as Timothy Wilson writes in his seminal Flags at sea. ${ }^{12}$ The phenomenon as such is, of course, familiar to art historians, but they have only noted it in passing. ${ }^{13}$ Political historians, even if increasingly interested in imagery and symbolism, have likewise bypassed the flag as an object of study. ${ }^{14}$ Indeed, scholarly interest in flags - and more particularly their history is decidedly meagre. As the Croatian scholar Željko Heimer observes, 'the science of vexillology is in its infancy'. ${ }^{15}$ 'Historical vexillology' as a subject of study is almost non-existent. ${ }^{16}$ This is partly the result of the fragmentary nature of historical information about flags. Details about flags and their colours remained obscure until the last decades of the seventeenth century, when flag books were printed with coloured reproductions. ${ }^{17}$ Even so, Goedde suggested that the abundance of flags in Dutch marine paintings may have underlined the extent to which the Dutch associated their national identity with the sea. ${ }^{18}$ The connection between flags and national identity has recently also been underscored by Gijs Rommelse. ${ }^{19}$ Likewise, according to Thomas Fulton in his classic study on sovereignty on the seas, 'to insult the flag was to insult the nation'. ${ }^{\circ}$

Taking Goedde's observation as a point of departure, the central question of this article is how flags in early modern Dutch paintings of naval battles can help us understand the construction of early modern identities. The approach is not so much art historical, but rather a case study in New Diplomatic History, the emerging literature that studies

10 Voorbeijtel Cannenburg, 'De zeeslag bij Gibraltar', 56, speaks of a 'mistake' in the painting by Cornelis Claesz. van Wieringen of Gibraltar when referring to a fictitious ship included in the painting to honour the patron. According to the website of Het Scheepvaartmuseum, the ship was 'as opposed to reality'. https://www. hetscheepvaartmuseum.nl/collectie/artikelen/666/ontdek-het-grootste-schilderij (Accessed on 28 September 2018).

11 Goedde, 'Het zeestuk als historie en metafoor', 59.

12 Wilson, Flags at sea, 9.

13 Goedde, 'Seafaring', 65; Goedde, 'Het zeestuk als historie en metafoor', 65-67; Daalder, 'Modello voor een schilderij', 37. Two recent articles that do study flags are Rommelse, 'National flags', and Brand, 'Vlagvertoon'.

14 Sharpe, Rebranding Rule, discusses all kinds of political symbols but hardly mentions flags. For an exception, see Davies, 'The birth of the imperial navy?', 23.

15 Heimer, Exploring Vexillology, 6.

16 But see for instance Trexler, 'Follow the flag'.

17 The first flag books were published in 1667: Beylen, 'Scheepstypen', 71; Smith, Flags through the ages and across the world, 50; Witsen, Aaloude en hedendaagsche scheepsbouw; Allard, Nieuwe Hollandse Scheepsbouw; Le Neptune François.

18 Goedde, 'Het zeestuk als historie en metafoor', 65. Cf. Schama, The embarrassment of riches, 37.

19 Rommelse, 'National flags'.

20 Fulton, The sovereignty of the sea, 477. 
the history of politics and international relations from a cultural perspective. ${ }^{21} \mathrm{I}$ intend to show the relevance of studying maritime art - in particular the depiction and positioning of flags - for illuminating the political aspirations of the fledgling republic in the international arena. I will do so by first introducing the discipline of vexillology. The article's second section is devoted to charting the variations of flags in these paintings, to show (in the third section) that the depiction of flags was often conscious and symbolic rather than random. Following from that observation, I will show how flags communicated political identities. More specifically, in the fourth and fifth sections I argue that these paintings reflected the identity of the Dutch Republic as a composite state, but also communicated aspirations about the Dutch Republic in the international hierarchy.

\section{Vexillology as a Developing Discipline}

Early modern naval flags signalled practical information, but also played their part in rituals that facilitated diplomatic naval communication. At a time when international hierarchy was highly contested, this became an important ingredient of the interaction between ships at sea. Flags could be lowered out of respect to a superior power, or could be captured as an act of humiliation. But flags were also connected to identity, to national pride, and more specifically to monarchical prerogative. Naval captains were extremely sensitive about matters relating to the flag. In 1652 Dutch ships refused to salute the English fleet, an incident that sparked the First Anglo-Dutch War. Naval historians have emphasised that respect for the flag was no idle ceremonial issue, but was considered of vital interest..$^{22}$ In this article, the focus will be on flags representing the identity of the ship, such as national, provincial, religious, or monarchical flags, rather than signal flags.

Testimony to the value attached to flags is the amount of space attributed to them in early modern works on ship-building and maritime matters. A telling example is Nicolaes Witsen's Aaloude en hedendaagsche scheeps-bouw en bestier (1690), a book on shipbuilding which discussed the variety of flags, their shapes, sizes, material, and significance in exhaustive detail. ${ }^{23}$ Witsen also underscored their political significance, publishing a detailed list of rewards a sailor might get for catching an enemy flag. These rewards were dependent on variables such as the size of the flag or the rank with which it was associated. Carel Allard's Nieuwe Hollandsche Scheepsbouw (1695) was really a flag book and contained a hundred pages of page-size full-colour illustrations of maritime flags of the world. ${ }^{24}$ Likewise, Le Neptune François (1693) contained elaborate information on and colourful reproductions of naval flags. ${ }^{25}$

Flags have been subject to a significant amount of empirical studies, but despite the emergence of vexillology as a field of study in the 196os, the function of the flag is a subject

21 Ebben and Sicking, 'Nieuwe diplomatieke geschiedenis'; Watkins, 'Toward a new diplomatic history'.

22 Davies, 'The birth of the imperial navy', 23.

23 Witsen, Aaloude en hedendaagsche scheeps-bouw.

24 Allard, Nieuwe Hollandse Scheepsbouw.

25 Le Neptune François, n.p. 
relatively unexplored in scholarly work. Vexillologists do not agree on a common definition. Whitney Smith formulated the following awkward but uncontested definition: 'A flag is the intentional combination of colors and shapes in a symbol, usually manifested on a piece of cloth or other flexible material, created to serve as a political or social communication between the user or users and one or more other individuals. ${ }^{26}$ Flags have great performative force because they are live things: the wind changes the shape of the flag continuously, and they can be hoisted and lowered. ${ }^{27}$ The functions of a flag are also relatively unexplored. Wilson distinguishes three functions for the flag, namely communication, festivity, and symbols of honour. Robert McCabe sees the flag as either a means of signalling or a symbol of personal authority or national identity. ${ }^{28}$

A new generation of vexillologists dug deeper into the nature of flags. Željko Heimer, in his study of the Croatian war in the 1990s, attempted a 'thick description' of flags. In his view the flag has a totemic function, symbolising and sacralising the identity of a society. ${ }^{29}$ It is this awareness of the totemic function of the flag that opens up the notion that political and religious identities are somehow encapsulated in the flag. According to Emile Durkheim in his work on primitive religion, the totem symbolises society, or collective identity. It is not simply a banner with which a society identifies itself, but indeed a sacred manifestation of that society. ${ }^{30}$ As such, the flag may very well act as a totem in societies, symbolising the sacred (religious or nationalist) nature of a society as a whole. According to Carolyn Marvin and David Ingle, in modern American culture the flag can represent the national soldier who has sacrificed himself to defend the nation, but in doing so he has replenished 'the vital energy of the totem'. In this view, the flag is the totem of the religion of American patriotism. ${ }^{31}$

Heimer, Marvin, and Ingle focus on modern uses of the flag, but Durkheim's totemic interpretations of symbols have also gained currency in early modern cultural and sociological studies, primarily with regard to the identities of social and religious communities. ${ }^{32}$ There is now also a burgeoning literature on early modern nationalism, but its connection to flags remains as yet unexplored. ${ }^{33}$ Scholarship on early modern flags in particular is very thin, partly because details about flags and their colours remain obscure until the second half of the seventeenth century, when flag books were printed with coloured reproductions. A study of how flags were represented in early modern art objects, such as paintings, as this article purports, remains unwritten. Precisely because flags were live things, but also ephemeral objects, studying their role via paintings enables us to recapture the ways in which flags performed their role in communicating identities.

26 Smith, 'What is the definition of "flag"?'.

27 It is, indeed, among the principles of vexillology that a good flag design must consider the continuously changing shape of the flag.

28 McCabe, 'Flags'.

29 Heimer, Exploring Vexillology, 6.

30 Riley, 'Flags, Totem Bodies, and the Meanings of 9/11', $721 \mathrm{ff}$.

31 Riley, 'Flags, Totem Bodies, and the Meanings of 9/11', 735; Marvin and Ingle, Blood Sacrifice and the Nation.

32 Holt, 'Putting Religion Back'.

33 E.g. Jensen, The Roots of Nationalism. 


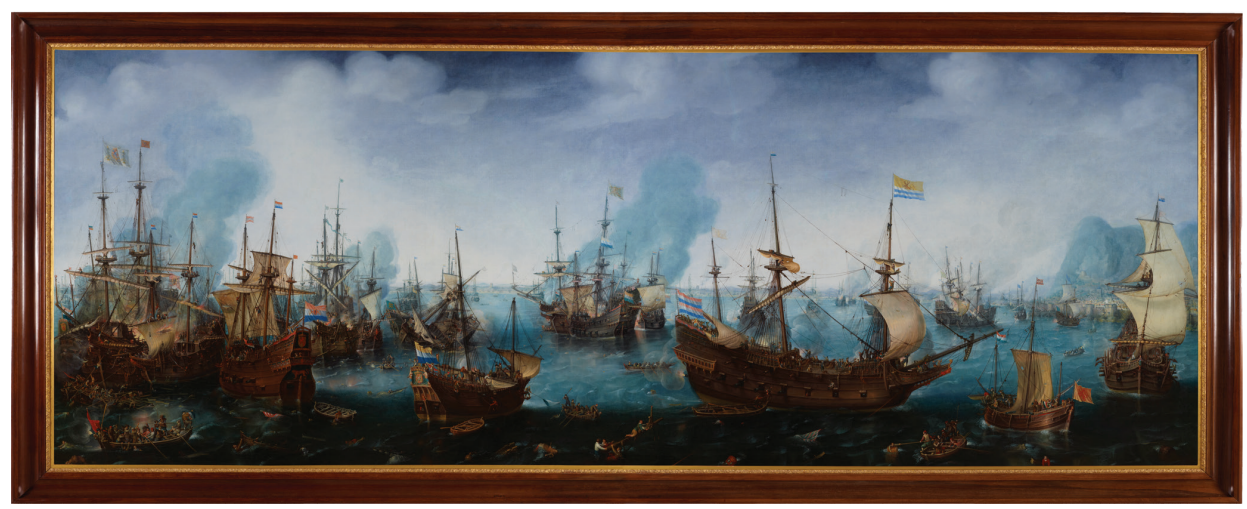

Fig. 2 Cornelis Claesz. van Wieringen, Battle of Gibraltar, 25 April 1607 (1622), oil on canvas, $180 \times 488 \mathrm{~cm}$, Amsterdam, Het Scheepvaartmuseum, A.o724.

\section{Motifs in Marine Art: The case of Van Wieringen's Battle of Gibraltar}

In order to study the connection between flags and identities, we must first establish the ways in which flags on paintings could represent identities. Since literature on this subject is virtually non-existent, this section has an empirical approach, charting the varieties of flags. The point is not so much to establish a definitive typology, but to show that the recurrent patterns of depictions of flags are sufficient proof that these were deliberate rather than random. By way of illustration, a useful point of departure is Cornelis Claesz. van Wieringen's magnificent ten-foot-wide Battle of Gibraltar (1622), an exuberant painting teeming with flags. Hendrick Vroom was approached by the Admiralty of Amsterdam to paint the scene, but turned the commission down, after which the Haarlem-based artist Van Wieringen (1577-1633) was contracted. He first produced a test version, followed by a modello, a smaller study, and finally his masterpiece (fig. 2), the latter two of which are now on display in Het Scheepvaartmuseum in Amsterdam. ${ }^{34}$ The painting has been subject to a considerable amount of analysis, but so far, the flags have received little attention. ${ }^{35}$

The Battle of Gibraltar took place on 25 April 1607, two years before the Dutch and the Spanish concluded a truce. The Dutch admiral Jacob van Heemskerck sailed up to Gibraltar with the intent of assaulting the Spanish fleet. The battle was a significant victory for the Dutch, as the Spanish fleet lost almost twenty ships whereas the Dutch fleet remained unscathed. One Spanish ship, possibly the Nuestra Señora de la Vega, was destroyed by an explosion, whereas the Spanish flagship the San Agustín surrendered. One of the few

34 Cornelis Claesz. van Wieringen, De zeeslag bij Gibraltar, 25 April 1607 (1622), Amsterdam, Het Scheepvaartmuseum, A.0724; Cornelis Claesz. van Wieringen, De zeeslag bij Gibraltar op 25 april 1607 (modello, 1622), Amsterdam, Het Scheepvaartmuseum, 2008.0106; Cornelis Claesz. van Wieringen, Het ontploffen van het Spaanse admiraalsschip tijdens de zeeslag bij Gibraltar (ca. 1621), Amsterdam, Rijksmuseum, SK-A-2163.

35 Voorbeijtel Cannenburg, 'De zeeslag bij Gibraltar'; Daalder, 'Cornelis Claesz. van Wieringen en de Zeeslag bij Gibraltar', 48-53, fig. 6; Daalder, 'Een zeeslag voor prins Maurits’, fig. 8; Brand, “"Een schilderije van de Slach van Heemskerck"'. 
casualties on the Dutch side was the admiral himself, Van Heemskerck, who was killed by a cannonball. The victory for the Dutch was immense; not only did they defeat the Spanish, they had done so in Spanish waters for the first time, bringing the war to Spain itself. Undoubtedly the Dutch victory accelerated the Spanish bid for the truce that was signed in $1609 .^{36}$

The painting shows a bewildering array of flags, which at first glance seem prominent and colourful but not necessarily arranged to convey meaning. However, a closer look reveals ideological purpose. Unsurprisingly, a fair number of the flags on the painting have been tarnished in some way: they are tattered, falling, burned, torn down, or drifting in the water. These recurring motifs, I argue, carry a political message.

The first motif that is striking in the painting is the denigration of religious flags. The painting does not allow us to read the names of the Spanish ships, which almost exclusively have religious connotations. The most significant ships in the story of the battle, the Nuestra Señora de la Vega, the San Agustín, and the Madre de Dios, serve as obvious examples. The Dutch ships, on the other hand, were almost all named after animals, such as De Gouden Leeuw (The Golden Lion) and De Zwarte Beer (The Black Bear). ${ }^{37}$ The painting alludes to the ships' names through the depiction of religious flags, common among Catholic seafaring nations. In Van Wieringen's Gibraltar paintings the Spanish flags stand out: they are colourful, large, and feature prominently in the foreground. Spanish ships often carried religious flags during this period, in addition to the Burgundian cross and the royal flag. ${ }^{38}$ Towards the left of the painting is a pink flag with a figure in blue and red, carrying a child; both are enveloped in a halo. ${ }^{39}$ No doubt this is a representation of the Virgin Mary and Jesus, an image consistent with the fact that it is flown from the ship of the Spanish vice-admiral, Nuestra Señora de la Vega, named after Mary.4.$^{40}$ it is plausible that depicting the flag torn and enveloped in smoke, emanating from the fire aboard, is a deliberate decision, rather than a reflection of historical reality, meant to denigrate the Catholic faith. The conscious choice of depicting this flag seems confirmed by the fact that Adam Willaerts's representation of the Battle of Gibraltar in the Prado museum shows no such flag. ${ }^{41}$

Van Wieringen more often played deliberately with the theme of religion. A spectacular test version of this painting, depicting an exploding ship at the very same battle of Gibraltar, is a case in point..$^{22}$ Among the people and items that are flung around by the explosion

36 Verster, 'De slag van Gibraltar door Vroom'.

37 The naming of ships in different national naval traditions in the early modern age is a subject yet to be explored in depth by naval historians. I owe this thought to David Davies, paper given at the conference The raid on Chatham of 1667 and its historical context, Amsterdam, 23 June 2017.

38 Wilson, Flags at sea, 53.

39 Cornelis Claesz. van Wieringen, Battle of Gibraltar, 25 April 1607 (1622), Amsterdam, Het Scheepvaartmuseum, A.0724.

40 According to David Blackmore, Warfare on the Mediterranean, 80, the ship on fire was the Madre de Dios, but I think he is mistaken. In the Van Wieringen painting, another ship flies a Virgin and child flag, vaguely visible just above the Amsterdam flag.

41 Adam Willaerts, La Batalla de Gibraltar, 25 de abril 1607 (ca. 1617), Madrid, Museo del Prado, Po7758.

42 Cornelis Claesz. van Wieringen, Het ontploffen van het Spaanse admiraalsschip tijdens de zeeslag bij Gibraltar (ca. 1621), Amsterdam, Rijksmuseum, sK-A-2163. 


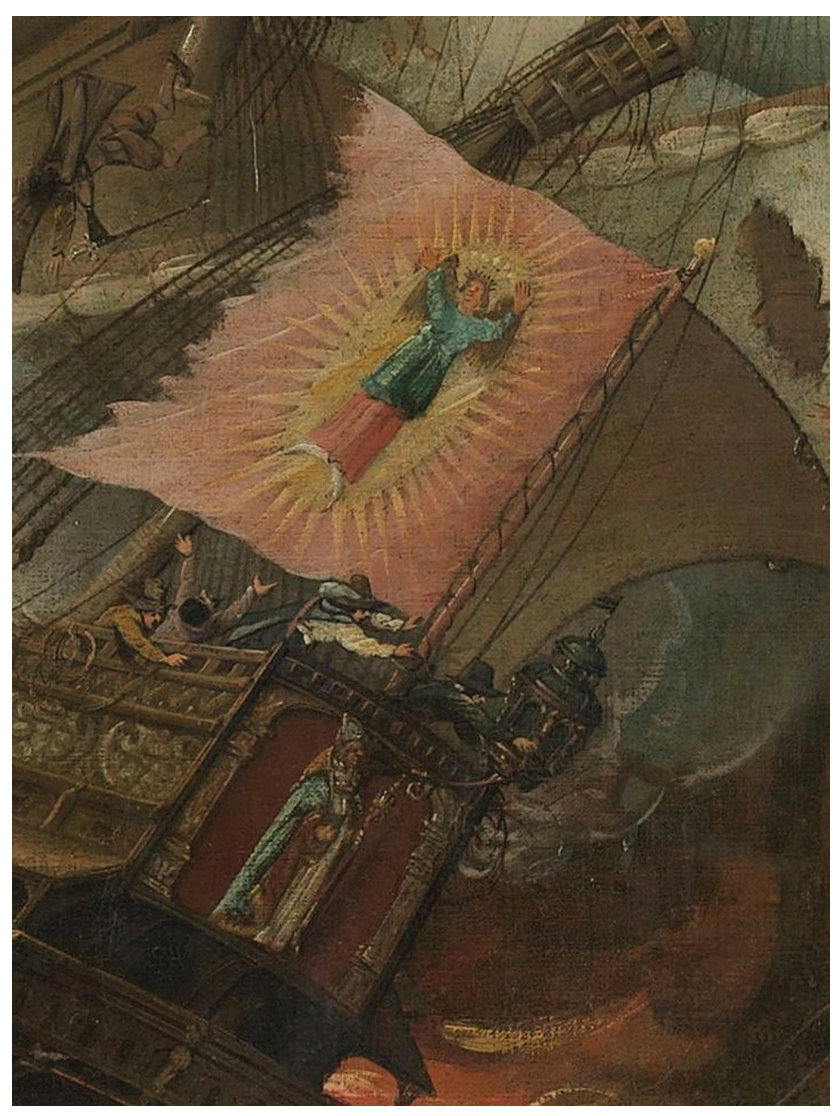

Fig. 3 Detail from Cornelis Claesz. van Wieringen, The Explosion of the Spanish Flagship during the Battle of Gibraltar, 25 April 1607 (c. 1621), oil on canvas, $136,8 \times 187 \mathrm{~cm}$, Amsterdam, Rijksmuseum, $\mathrm{sK}-\mathrm{A}-2163$.

is a monk, toppling over with his buttocks bared, no doubt a satirical detail. A statue of a saint is clearly visible on the stern. On the rear mast flies a flag depicting the Virgin Mary, standing on a crescent, in blue, crowned, against a pink background, and with a halo (fig. 3). The flag is clearly torn. Directly underneath the flag, almost touching it, is a man crying out for help, apparently to the Virgin figure. Presumably it is in jest, because Mary, in danger of being destroyed herself, is clearly not able to lend assistance. On the main mast is a yellow flag of St. George slaying the dragon. The flag is untarnished, but flying from a sinking ship it also discredits Catholic military prowess. Given the repeated imagery of Catholic flags being torn and devalued, it seems fair to suggest that the motif is intentional.

This is consistent with what we know of Dutch marine culture. For instance, puns on Spanish Catholic flags and names of ships were common in contemporary sailors' songs. A critical poem on a sea battle in 1624 , for instance, is scathing about the Spanish custom of naming ships after saints, Mary, or the Holy Ghost, arguing that it is presumptuous: the 


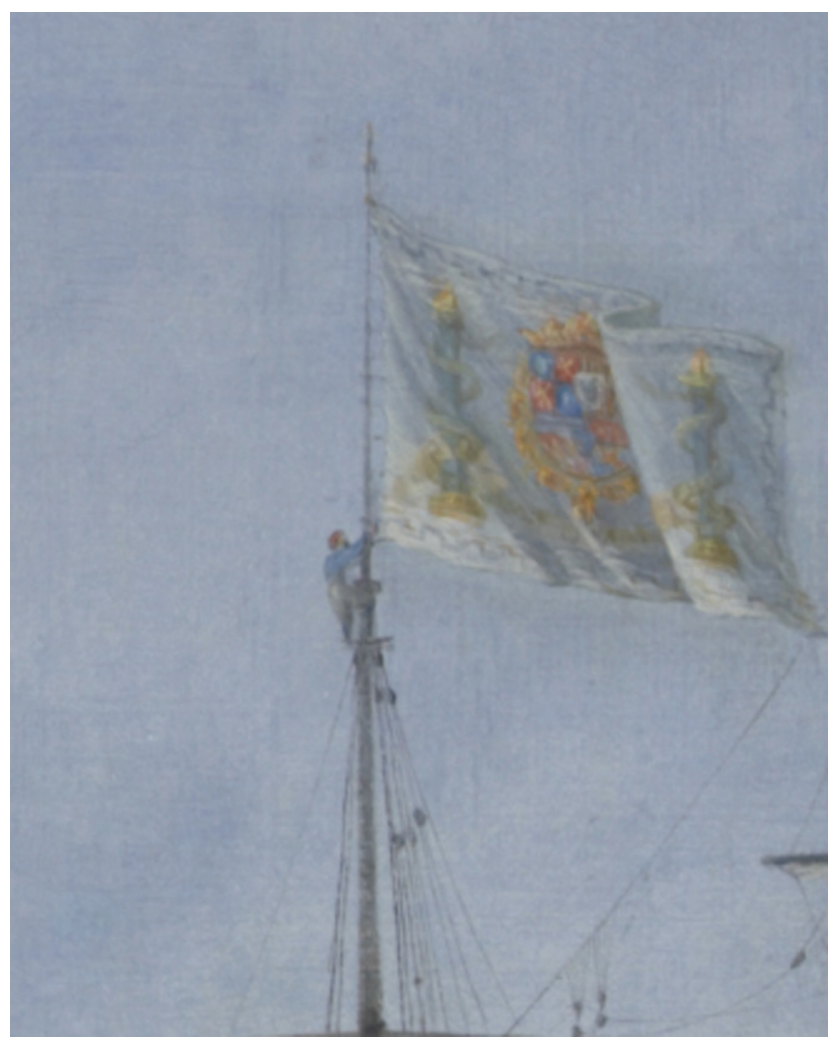

Fig. 4 Detail from Van Wieringen's Battle of Gibraltar, Amsterdam, Het Scheepvaartmuseum, A.0724.

sinking of one of those particular ships was therefore a punishment from God. ${ }^{43}$ Another one, on the Battle of Gibraltar of 1607, satirises the defeated Spanish who had to fly the white flag and 'sing their misericords'. ${ }^{44}$ A similar poem on Gibraltar satirises the 'torn cross' in the banner of a Spanish flag, whereas another hails the 'battle for the true faith'. The same poem praises the act of tearing down the 'torn cross'. ${ }^{45}$ In historical context, it seems plausible to suggest that the discrediting of Catholic images echoes the Iconoclastic Fury of 1566, when Dutch Calvinists removed or destroyed statues and images of saints from Catholic churches.

The image of the torn religious flags as discussed above leads to a second motif, namely the damaged enemy flag as a symbol of political independence. A fascinating detail is seen on the far left of the Battle of Gibraltar, where a Dutch sailor climbs the mizzen of the Nuestra Señora de la Vega, reaching for the flag, apparently about to bring it down (fig. 4). The flag is not the Burgundian cross, ubiquitous on Spanish ships, but the spectacular royal standard of the King of Spain. Clearly visible is the coat of arms of Philip III, flanked by the

43 Songs about Gibraltar are discussed in Scheurleer, Van varen en van vechten, I, 146-147.

44 Scheurleer, Van varen en van vechten, I, 87, 89.

45 Scheurleer, Van varen en van vechten, I, 91. 


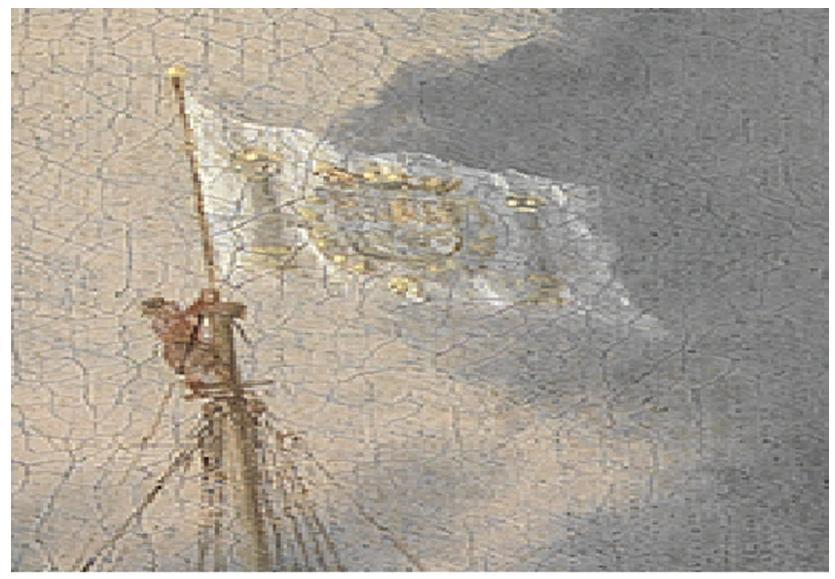

Fig. 5 Detail from Adam Willaerts, La Batalla de Gibraltar, 25 de abril 1607 (ca. 1617), oil on canvas, $78,3 \mathrm{~cm} \times 121,5$, Madrid, Museo del Prado, Po7758.

symbol of the Order of the Golden Fleece. ${ }^{46}$ The scene of the sailor capturing the royal flag as depicted by Van Wieringen is represented in exactly the same way in Adam Willaert's piece on Gibraltar, now in the Prado Museum in Madrid (fig. 5). The detail is significant because that particular flag may very well be the most central feature of the whole painting. From contemporary sources we know that the Dutch admiral Van Heemskerck promised fifty pieces of eight to the first man one who captured the enemy admiral's flag. This was a customary incentive. The States-General awarded generous prizes for capturing an enemy flag, depending on size and rank. ${ }^{47}$

The scene did not spring from the imagination of the two painters, but is based on the published eyewitness account of the Battle of Gibraltar by Joris van Spilbergen, which indeed described the action of a sailor and his capture of the flag. ${ }^{48}$ The taking of flags at Gibraltar is confirmed by a letter from the Admiralty of Amsterdam in 1607, showing how several of these flags were presented to the States-General as a sign of victory. ${ }^{49}$ The fact that Van Wieringen's depiction is an almost exact copy of that of Willaert suggests that he was familiar with Willaert's painting. Even so, the simulation must have been deliberate, as the scene is depicted slightly differently on the modello. The iconography of the scene is striking: a Dutch sailor bringing down the flag of the King of Spain himself, in clear view of everyone. I would argue that the scene is a performative act of profound significance. It would certainly have been considered a personal affront to the king, since the royal standard could only be used by him or a representative of the crown, in this case the fleet admiral. Contemporary poems confirm that the Battle of Gibraltar was a victory over 'the

46 Closer inspection shows some inconsistencies with the actual flag of Philip - the coat of arms of Portugal on the painting seems to be missing - but this is undeniably the Spanish royal standard.

47 Witsen, Aaloude en hedendaagsche scheeps-bouw, 450, 466.

48 Van Spilbergen, Copye van een brief.

49 The Hague, Nationaal Archief, Archief van de Admiraliteitscolleges, 1536, Letter from the Admiralty of Amsterdam, received 31 August 1607, fol. 85v. 
great Armada of the King' and rejoice that the 'King's ships were burning'.$^{50}$ Doing so in the very harbour of a Spanish port, in front of the Spanish military but also the citizens of Gibraltar, was powerful in its effect. It is also likely that this ideological message was opportune seeing as it came at the resumption of the war with Spain in 1621, a war in which the King of Spain intended to recapture the provinces he had lost. I have found no corroborating evidence, but speculate that the performative act echoes the Act of Abjuration of 1581, in which the seven provinces rejected Philip II as their sovereign and overlord. By tearing down the royal standard, the rejection of the King of Spain is re-enacted and confirmed.

A third motif is related to the themes of victory and loss. In addition to the damaged or captured flag, a motif is the flag that has been torn down, of which there are generally three variants: the flag has fallen from its position, is just above water on a drifting broken mast, or is floating in the water. Van Wieringen's Gibraltar piece shows variations on the floating flag. There are three floating flags in the water, distributed more or less evenly over the width of the painting in the foreground, which suggests the images are not random. The floating flag to the right appears to be a Prince's flag with four or five repetitions of the red-white-blue (fig. 6). The repetition here refers to rank: four tricolour bands point to an admiral, three to a vice-admiral, and two to a rear-admiral..$^{51}$ The image may appear random, but on closer inspection I believe it is a deliberate choice. Since no Dutch ship was lost in the battle, the loss of a Dutch flag seems odd. However, the Dutch did suffer losses: approximately a hundred Dutchmen were killed in action and some sixty suffered injuries. Among the casualties was the admiral of the Dutch fleet, Jacob van Heemskerck. It was customary that when the commander of the fleet was killed, the flag was lowered out of respect. In practice this never happened, so as not to lower the morale of the fleet's sailors. Indeed, eyewitness reports tell us that when Van Heemskerck was killed by cannon fire, his death was kept a secret. ${ }^{22}$ The painter may have wished to honour the fallen admiral by depicting his flag in the water. The flag here clearly has a totemic function as described above: it represents the sacrifice that has been made for the nation, enforcing its meaning as a sacred symbol of the collective. ${ }^{53}$ Van Heemskerck received an elaborate funerary monument and is usually seen as the first Dutch national naval hero.

The most striking feature of the Gibraltar piece is a scene which historians have been at a loss to interpret (fig. 7). A Dutch sailor is standing on the anchor of the ship, trying to salvage what seems to be a white flag from the water. The scene is not mentioned in any of the contemporary sources, such as Van Spilbergen, and therefore it is presumably fictional. But it seems telling that Van Wieringen showed the scene in the very centre in his final work. At first glance it looks as though the sailor is competing or cooperating with a sailor on a nearby sloop for the flag. But the modello shows the same scene, in which the man on the anchor is clearly on his own, so the flag seems uncontested. The main difficulty is in the identification of the flag, which in the modello seems blue (or possibly a shade of white)

50 Scheurleer, Van varen en vechten, I, 89, 92, 183. 222, 223.

51 Allard, Nieuwe Hollandse Scheepsbouw, 14.

52 Witsen, Aaloude en hedendaagsche scheeps-bouw, 455.

53 The connection between the flag and the honour of the admiral is confirmed in sailors' poems: Scheurleer, Van varen en vechten, I, 315, 369. 


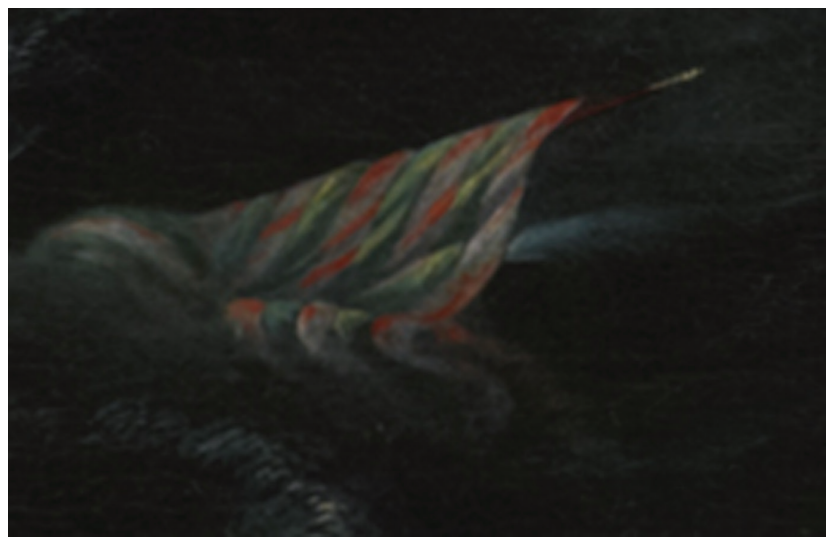

Fig. 6 Detail from Van Wieringen's Gibraltar, Amsterdam, Het Scheepvaartmuseum A.o724.

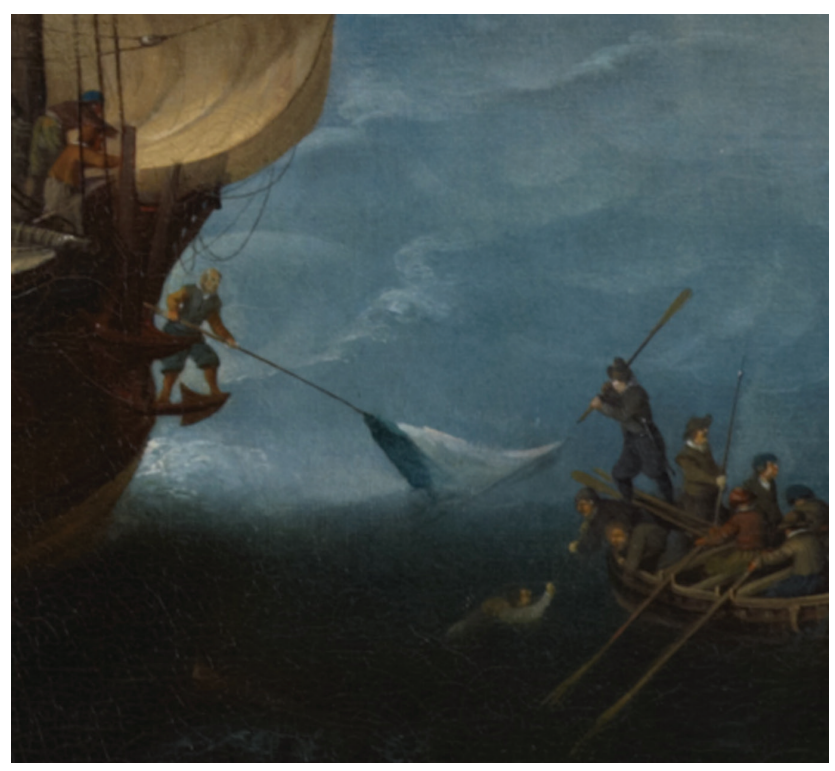

Fig. 7 Detail from Van Wieringen's Gibraltar, Amsterdam, Het Scheepvaartmuseum A.o724.

but in the final version white. The flag touching the water should be seen as an insult or humiliation, so the scenes depicting the flag in the water must be interpreted accordingly. I would argue, though, that given the symbolic nature of the flags we have seen so far, the scene represents the defeat of the Spanish fleet as a whole. It has a probable basis in the sources, for the Spanish flag ship, the San Agustin, was flying the white flag to signal surrender. Realistically, since that ship is far in the background of the painting, this could not be that white flag, but the painter may have transferred the white flag to the foreground so as to make it more visible, separating the actual scene from the corresponding metaphor. 
Gijs Rommelse has shown this specific way of separating scene and metaphor on another, similar painting. ${ }^{54}$

In conclusion, a short survey of flag motifs in the Gibraltar piece has shown that representing flags in maritime battle paintings cannot be seen as a simple imitation of historical events or as a way of adding colourful detail. They were intentional and indicate a vexillological iconography, some characteristics of which have been pointed out above. It is clear that the portrayal of flags in marine paintings shows certain patterns, each of which seems to have a specific meaning. In order to take this argument further, I suggest that this vexillological iconography points to, but is not limited to, two larger themes. The first theme is connected to multiple identities, represented by the religious, admiralty, provincial, and national flags. The second theme is the negotiation of international hierarchy, as represented by the humiliation of the flag. These themes will be the subject of the following two more extensive case studies.

\section{Flags and Multiple Identities}

Firstly, then, the flag arrangements in these paintings represent the multi-layered make-up of the Dutch body politic. It was vital for a young seafaring nation to assert itself in international waters, hence the choice of flying the tricolour on all ships in marine paintings. Although the Dutch fleet was composed of the contributions of the provinces and admiralties, national coherence was underscored by the use of the States flag, obligatory on all warships from 1596. The connection between this flag and an emerging national identity is suggested in modern scholarship, but also in contemporary popular culture. In a sailors' song of 1619 the States flag and 'praise' for the 'pious Batavians' are explicit. ${ }^{55}$ Another song speaks of the 'united Netherlands against their common enemy'. ${ }^{6}$ However, the emphasis of current literature on the 'nation' with reference to these paintings does not sit well with the federal make-up of the Dutch Republic and its multiple identities, nor with the fact that early modern nationalism was rudimentary at best. ${ }^{57}$ Indeed, most paintings show more diversity. Remmelt Daalder has already suggested that in addition to national unity these paintings also reflected regional identities..$^{8}$ An example is the colourful painting attributed to Hendrick Vroom, now in Het Scheepvaartmuseum, of the Battle of Sluis (1603), pitting Dutch ships against Spanish galleys (fig. 8). The Spanish flag arrangements do not seem consistent, carrying the red blood flags, but also the red-and-white-striped flag and variations on the Burgundian Cross. ${ }^{59}$

54 Rommelse, 'Het vernederen van een vlag'.

55 Scheurleer, Van varen en van vechten, I, 132.

56 Scheurleer Van varen en van vechten, I, 82.

57 According to Beylen, the States flag that was introduced in 1596 'was probably meant as an official symbol of the state': Beylen, 'Scheepstypen', 69. He also speaks of the 'national flag'.

58 Daalder, 'Zeegeschiedenis op schilderijen', 37.

59 Hendrick Cornelisz. Vroom, De slag bij Sluis tussen Hollandse en Spaanse galeien, 26 mei 1603 (ca. 1603), Amsterdam, Het Scheepvaartmuseum, 1990.0746. The title given by the museum is obviously erroneous, since the ships were not so much from Holland as from Zeeland. 


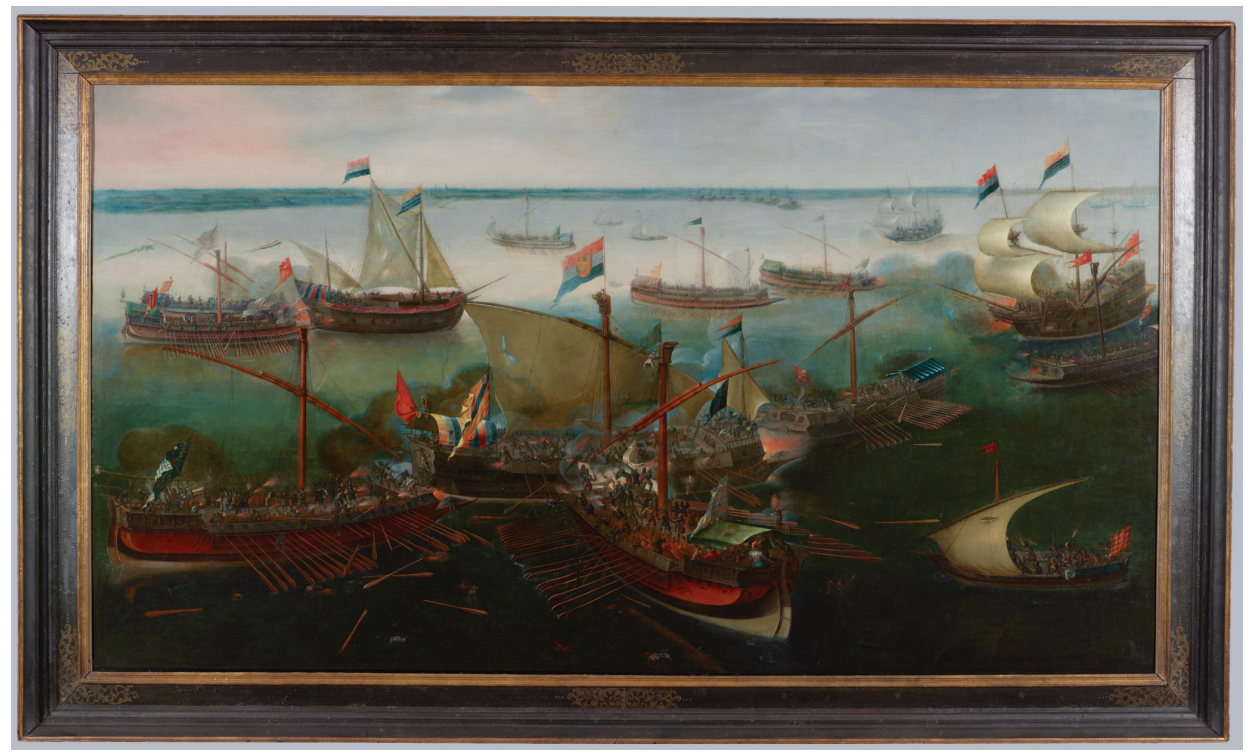

Fig. 8 Ascribed to: Hendrick Cornelisz. Vroom, The Battle of Sluis between Holland and Spanish galleys, 26 May 1603 (ca. 1603), oil on canvas, 132,5 × 240 cm, Amsterdam, Het Scheepvaartmuseum, 1990.0746.

The same applies to the Dutch ships, which fly the red-white-blue on each ship, but also provincial and city flags. Clearly visible is the flag of the city of Middelburg in the centre, and various Zeeland flags, consistent with the fact that the battle was largely waged by Zeeland ships. Whereas the painting thus clearly represents Dutch unity through the usage of a national flag, there is also space for celebrating multiple provincial and urban identities. This is also the case in Vroom's portrayal of an encounter between a Dutch and an English ship around 1605 , as discussed in the introduction of this article. ${ }^{60}$ Several ships are engaged in battle, two of which are prominently depicted in the foreground and carrying several flags. Vroom was known for painting flags in striking colours, and in this painting the bright red of the flags stands out among the dark grey colours of the sea and the light grey sky. The English ship flies four flags. On the stern is a Royal Navy Stuart pennant of eleven red-and-white stripes. The mizzen and fore masts carry the St. George's cross (red on white), whereas the main mast flies the Stuart royal standard, a coat of arms flanked by a lion (England) and a unicorn (Scotland). The English national flags are placed lower than the royal Stuart standard, indicating the primacy of the king over the nation. ${ }^{61}$ The Dutch ship has the red blood flag on the stern, and the Prince of Orange's flag on the fore and mizzen. The main mast carries the prince's flag with the coat of arms of Amsterdam. Thus, rather than pitting England against the United Provinces, the painting singles out

6 Vroom, Schermutseling. See also figure 1.

61 Allard, Nieuwe Hollandse Scheepsbouw, 9. 
the Amsterdam flag and the royal standard, adding layers of identity to what ostensibly seems an Anglo-Dutch encounter. ${ }^{62}$

Therefore, although the ubiquity of the tricolour in naval battle scenes is striking, I would argue that the paintings can also be read as more subtle representations of multi-layered identities. Several historians have convincingly stated that the dominance of the tricolours on Dutch ships strengthened the formation of a Dutch national identity on the fleet. As such, the national flag was clearly connected to the process of state formation. ${ }^{63}$ Nevertheless, it is still the case that whereas national flags may have been dominant, there were other flags present. I have already noted the religious flags on Spanish ships, but also the royal standard. The United Provinces, certainly in the early decades, were largely an alliance of cities and provinces, and arguably the depiction of the national flag in paintings lent force to gravitational nationalistic forces. But the paintings also allow identities other than just the Dutch national identity to be represented.

A close examination of Van Wieringen's Gibraltar piece reveals an interesting pattern of images that together symbolize multiple identities within the Dutch Republic. On the left floats a flag with repeated red-and-white stripes, one that is not obviously identifiable. It resembles the Stuart royal ensign, and there seems to have been an old Spanish flag consisting of red-and-white stripes, which is visible in a painting by Hendrick Vroom of the Battle of Sluis. ${ }^{64}$ However, I would suggest that the flag is related to the city of Hoorn, as can be gleaned from a painting by Vroom in $\mathbf{1 6 2 2}$ of the port of Hoorn, in which the city flag was painted for the first time. ${ }^{65}$ Three more flags, in addition to the tricolours, are also clearly visible. The ship of Vice-Admiral Alteras, De Roode Leeuw (The Red Lion), was equipped by the Admiralty of Zeeland and flies the Zeeland flag (fig. 9). Attacking the Nuestra Señora de La Vega is an Amsterdam ship, clearly marked by the Amsterdam flag. Lastly, the Frisian flag (two golden lions on a field of blue) is shown on a ship in the centre area of the painting. ${ }^{66}$

Indeed, what seems a random configuration of flags is actually deliberate, for these flags represent the admiralties of the Dutch Republic: the Frisian admiralty in Harlingen, the Zeeland admiralty in Veere and Vlissingen, the admiralty of the Northern Quarter in Hoorn, and the Admiralty of Amsterdam. The one admiralty not clearly represented is the one in Rotterdam, but one version of that flag is simply the tricolour, which is visible all over the painting. ${ }^{67}$ The ship attacking the San Agustin, in the centre of the painting, was commanded by the Rotterdam Vice-Admiral Mooy Lambert, and indeed it flies the tricolour. Two facts support the hypothesis that all five admiralties are intentionally represented in the painting. Firstly, on the very right of the painting is a ship with on its prow a figurehead of a girl with a blue skirt on which three silver fish are visible: the coat of arms of the city of

62 Russell, Visions of the sea, 160, states that the Dutch refused to salute.

63 E.g. Rommelse, 'National flags'. Lawrence Goedde also sees a connection between the flag and an emerging national consciousness: Goedde, 'Het zeestuk als historie en metafoor', 65.

64 Hulme, The flags of the world, plate viI, example 52.

65 Hendrik Cornelisz. Vroom, Gezicht op Hoorn (1622), Hoorn, Westfries museum, inv. no. 01729.

66 I thank Remmelt Daalder for suggesting this to me.

67 The Rotterdam flag is green and white, but the flag of the Admiralty of the Maze was red, white and blue (according to the Neptune Françoise, n.p.), sometimes with the letters 'AOM' in the white field. 


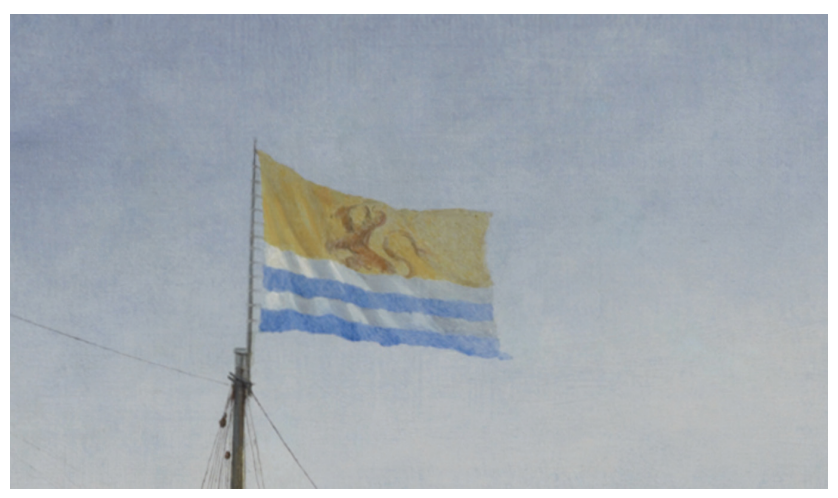

Fig. 9 Detail from Van Wieringen's Gibraltar, Amsterdam, Het Scheepvaartmuseum, A.o724.

Enkhuizen.$^{68}$ Since Enkhuizen and Hoorn jointly maintained the admiralty of the Northern Quarter, the Enkhuizen arms and Hoorn flag combined in the painting are telling. Secondly, in the painting by Adam Willaerts of the Battle of Gibraltar, hardly any admiralty flags are visible, except that of Zeeland. The hypothesis is consistent with the fact that all admiralties were represented at the Battle of Gibraltar, as James Bender has shown. ${ }^{69}$ The fact that Willaerts did not do so, while Van Wieringen made sure that all six admiralty ports were represented, surely indicates a conscious choice. Moreover, the deliberate decision to add flags and coats of arms to paintings can also be seen in Van Wieringen's invention of an Amsterdam ship in his painting and his inclusion of the coat of arms of Prince Maurice, in order to please his patrons. The actual ship never existed. This notion is strengthened by the fact that the Amsterdam ship commands the centre of the painting. ${ }^{70}$

Adding one final detail is the use of flags of the States-General in the painting. ${ }^{71}$ It thus appears that the painting represents both the federal make-up of the United Provinces and their fleet through the deliberate depiction of the symbols of all the admiralties, as well as unity through their combination, as represented by urban, provincial, and federal flags. In short, the painting is a metaphor of the multiple identities that form the body politic of the Dutch Republic.

\section{Flags and the Negotiation of International Hierarchy}

In addition to representing the Dutch body politic, the depiction of flags conveys meaning about the position of the Dutch Republic in the international sphere. The princes of the early modern age were obsessed with international hierarchy. The Holy Roman Emperor was recognized as the first among them all, followed by kings, republics, and free cities. Tradition

68 Voorbeijtel, 'De zeeslag bij Gibraltar', 56.

69 Bender, Dutch warships in the age of sail, 46.

70 Daalder, 'Een zeeslag voor prins Maurits', 10.

71 Daalder, 'Cornelis Claesz. van Wieringen en de Zeeslag bij Gibraltar in 1607', 48, fig. 6. 
determined international hierarchy, which seemed fixed, but was in practice malleable. Indeed, continuous quarrels between ambassadors over precedence typify the diplomatic history of the age..$^{72}$ The Dutch Republic went to great lengths to fight its way into the established hierarchy. Only after the formal recognition of its independence in 1648 was it agreed that the States-General would occupy a place just behind the Republic of Venice. Even so, their self-assumed title of 'High Mightinesses' was not universally recognized until well into the eighteenth century. ${ }^{73}$ This hierarchy translated itself into set procedures at sea as well. In general, ships were required to salute ships that represented a higher-ranking sovereign. Dutch ships were thus expected to greet ships from kingdoms by a cannon salute, lowering and hoisting the flag, or lowering sails, although these rituals also depended on whether the ships met at full sea or not. ${ }^{74}$ The refusal or failure to do so could lead to real conflict. ${ }^{75}$

It is precisely this established hierarchy and its contestation that makes the study of flags in the early modern age important. Indeed, in his 1695 study of naval flags Carel Allard consciously challenged the established European hierarchy and favoured the maritime nations over the traditional leaders of Europe, proposing an alternative, or perhaps parallel, hierarchy. Listing the naval flags of Europe, rather than following the familiar pattern of Emperor and pope, followed by kings, republics, and archdukes, he commenced with England and the Netherlands. 'As far as the rank of flags is concerned', he writes, 'it is undeniable that the English and the Dutch are the most powerful at sea, which is why we have accorded them precedence. ${ }^{76}$ The list is, oddly, followed by the pope, out of respect for the ancient order, and then Spain, Portugal, and Italy (being the three 'oldest and first sea-farers'), followed by France. ${ }^{77}$ This was not in line with international treaties, for the Dutch had acknowledged French precedence at sea. ${ }^{78}$ The list continues with the Scandinavian kingdoms and ends with the Ottoman Empire. The contemporaneous Neptune Françoise (1693) follows a strikingly similar order, but it starts with France, which is followed by England, the Dutch Republic, Spain, Italy, and the Scandinavian kingdoms. ${ }^{79}$ Thus, naval flag books challenged the traditional international hierarchy by moving away from its bias towards those wielding power on land in favour of the naval powers of the late seventeenth century: England, France, and the United Provinces.

In addition to these flag books, paintings with flags were also in dialogue with the diplomatic conventions of the age regarding international hierarchy, in two distinct ways. The first is related to the motif established above concerning the tarnished flag. As we have seen, one way to do so was to portray the enemy flag in a humiliating posture. The Gibraltar painting by Van Wieringen does so by showing flags as either being torn, fallen into the water, or being captured by a Dutch sailor. This theme can be observed in other similar paintings. Het Scheepvaartmuseum owns a painting by Willem van de Velde of

72 Geevers, 'The diplomatic battle over precedence'.

73 Aalbers, De Republiek en de vrede van Europa, 152.

74 Van Beylen, 'Schepen op kaarten ten tijde van Gerard Mercator', 71.

75 On this theme, see Fulton, The sovereignty of the sea; Davies, Kings of the Sea.

76 Allard, Nieuwe Hollandse Scheepsbouw, preface.

77 Allard, Nieuwe Hollandse Scheepsbouw, preface.

78 Witsen, Aaloude en hedendaagsche scheeps-bouw, 341.

79 Neptune Françoise, n.p. 


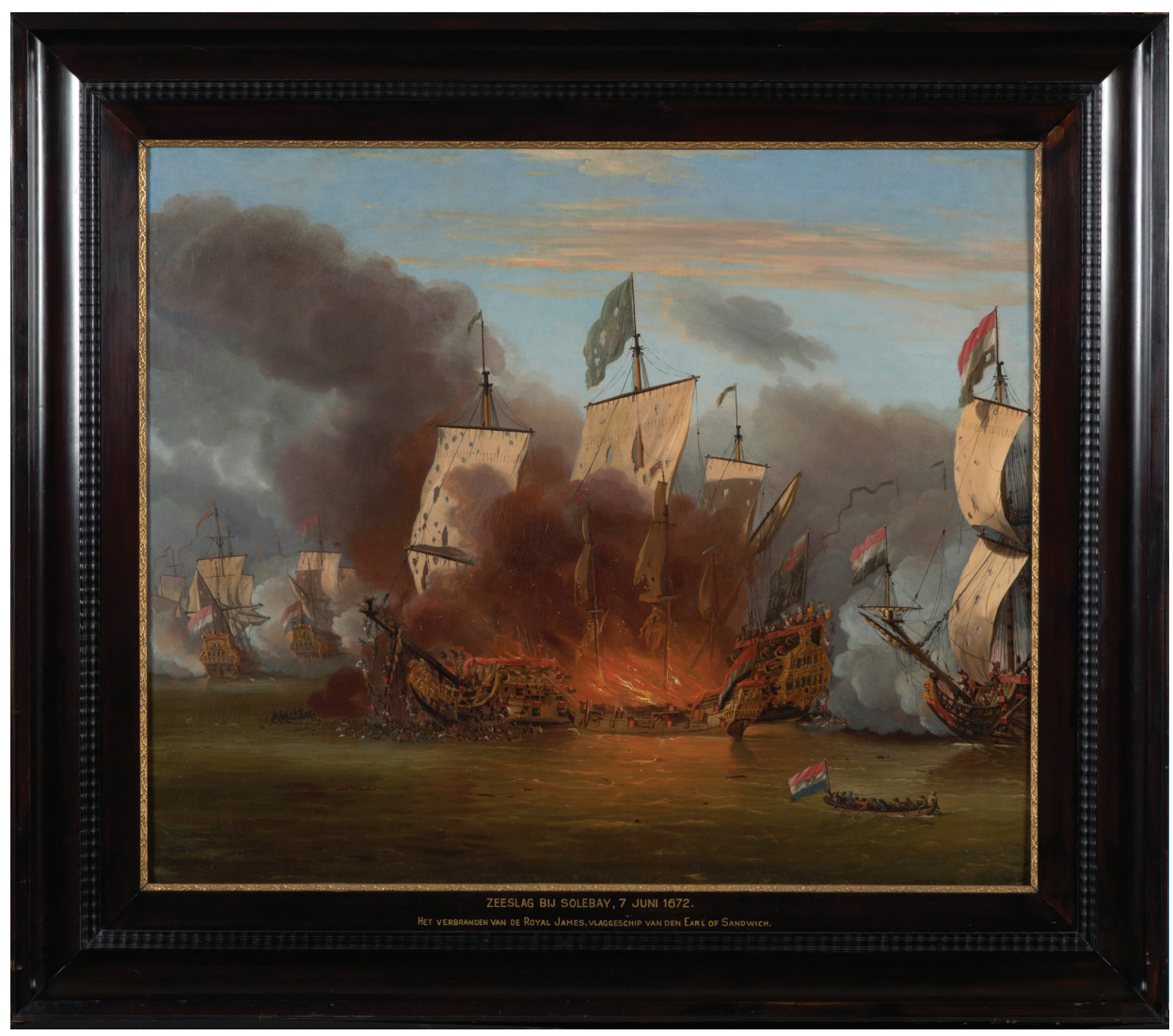

Fig. 10 Willem van de Velde II, Battle of Solebay, 7 June 1672 (c. 1675), oil on canvas, $77 \times 91,5 \mathrm{~cm}$, Amsterdam, Het Scheepvaartmuseum, A.ooo4.

the 1672 Battle of Solebay during the Third Anglo-Dutch War (fig. 10). ${ }^{80}$ A Dutch fireship successfully attacked and sank the flagship the Royal James, commanded by the Earl of Sandwich. The painting depicts the moment that the ship has caught fire. Prominent in the painting is the flag on the main mast of the Royal James, blackened from smoke or fire, and with visible burn-holes. It would have been the royal standard, so the tarnished flag was a denigration of the king's person. ${ }^{81}$ This is a significant detail, for the English declaration of war of 1672 specifically stated that Dutch insult to the King of England was a casus belli. ${ }^{82}$

The declaration of 1672 connects the honour of the flag squarely to the English claim to the dominion of the sea. Whereas the Dutch laywer Hugo Grotius argued for freedom of

8 Willem van de Velde II, Zeeslag bij Solebay, 7 juni 1672 (ca. 1675), Amsterdam, Het Scheepvaartmuseum, A.0004.

81 Curiously, the painting was probably painted in England for presumably an English client: Daalder, 'Help, een brander', 12-13.

82 His Majesties Declaration against the States Generall. 


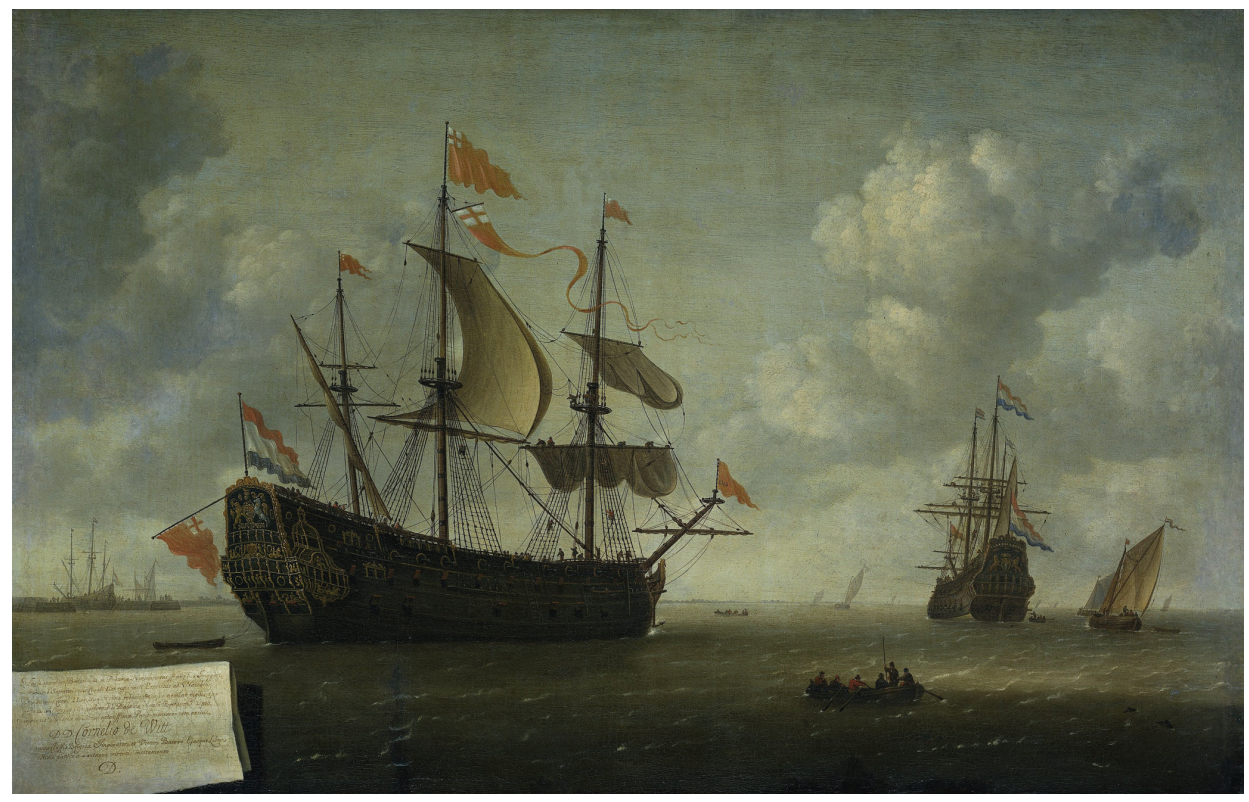

Fig. 11 Jeronymus van Diest, The Arrival of the English Flagship 'Royal Charles' at Hellevoetsluis, Captured during the Dutch Raid on the Medway, June 1667 (1667-1672), oil on canvas, $68 \times 103,5 \mathrm{~cm}$, Amsterdam, Rijksmuseum sK-A-1389.

the seas, John Selden wrote in favour of the English dominion over the waters surrounding Britain. The issue of dominion frequently flared up during the remainder of the century. Charles II in particular seemed strongly committed to upholding the claim to the dominion of the seas. The theme of dominion is also visible in another painting by Van de Velde, a scene from the second Anglo-Dutch War, where we see the flagship The Royal James in dire straits. ${ }^{83}$ The mizzen is broken and the mast is collapsing, taking with it the Union Jack in its fall. The moment is captured with sardonic precision. The main mast is about to be broken, so the royal flag is about to tumble as well. ${ }^{84} \mathrm{~A}$ final example is Jeronymus van Diest's painting of the capture of the Royal Charles during the 1666 Raid on Chatham (fig. 11) ${ }^{85}$ During the Second Anglo-Dutch War, a Dutch fleet sailed up the River Medway, burned part of the English fleet and captured the flagship, towing it back to Holland. The naval action accelerated the end of the war. The painting shows flags with the St. George's cross on all masts, but not on the stern, where the English flag is upside down and replaced by the Dutch States' flag.

83 Willem van de Velde II, Het wegslepen van de Royal James tijdens de Vierdaagse Zeeslag, 1666 (1666-1670), Amsterdam, Het Scheepvaartmuseum, A.0296.

84 Rommelse, 'Het vernederen van een vlag'.

85 Jeronymus van Diest, Het opbrengen van het Engelse admiraalschip de 'Royal Charles', buitgemaakt tijdens de Tocht naar Chatham, juni 1667 (1667-1672), Amsterdam, Rijksmuseum, sK-A-1389. 


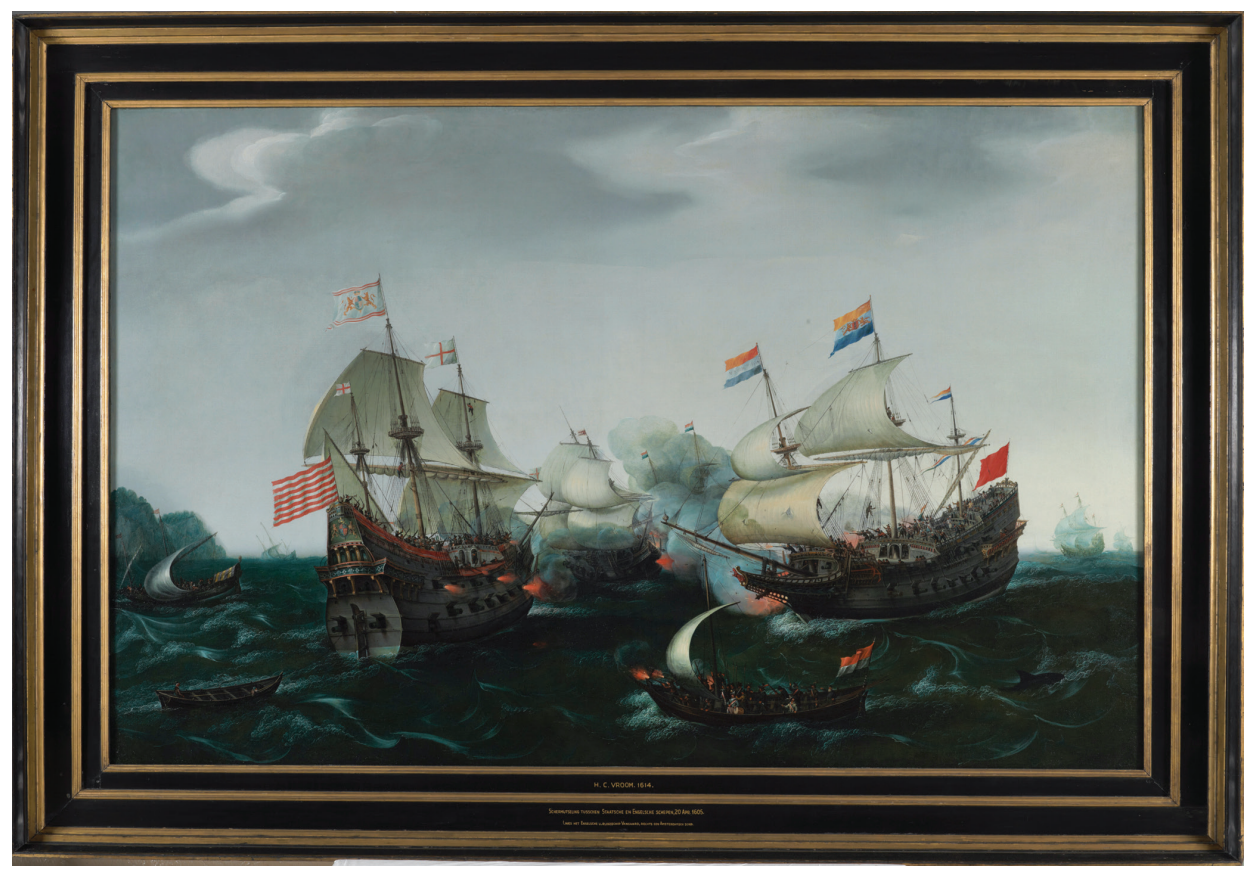

Fig. 12 Vroom, Skirmish, Amsterdam, Het Scheepvaartmuseum A.ooo2.

Whereas the motif of the humiliated flag is obvious in a range of paintings, there is yet another way in which international hierarchy is negotiated, namely through the positioning of flags. If we look again at Vroom's painting of the encounter between an English and a Dutch ship, it might be interpreted as a Dutch challenge to the English claim to dominion (fig. 12). ${ }^{86}$ Yet I believe the message is more complex: it is striking that in the painting, the Stuart flag is depicted slightly higher than the Dutch flag. This suggests the Dutch acknowledged their inferior position to the English crown, even if they challenged the English claim to dominion as such.

My hypothesis is that the positioning of flags in paintings of naval battles reflects interpretations of and challenges to international hierarchy. This is consistent with actual diplomatic practice, in which the lowering of the flag (and thus its relative position) was an acknowledgment of this hierarchy. Of course, in the Vroom painting this might just be a coincidental feature, so we need corroboration. As we have seen, in the Van Wieringen painting of Gibraltar the Spanish flags were humiliated. Even the royal flag flying from the Nuestra Señora de la Vega is being torn down. Nevertheless, the superiority of the Spanish royal flag - shown on the far left side of the painting on the ship of the Spanish vice-admiral - is striking, as it symbolizes the precedence of the Spanish Crown over the States-General. It is at the same height as a barely visible Dutch flag in the centre, but the 


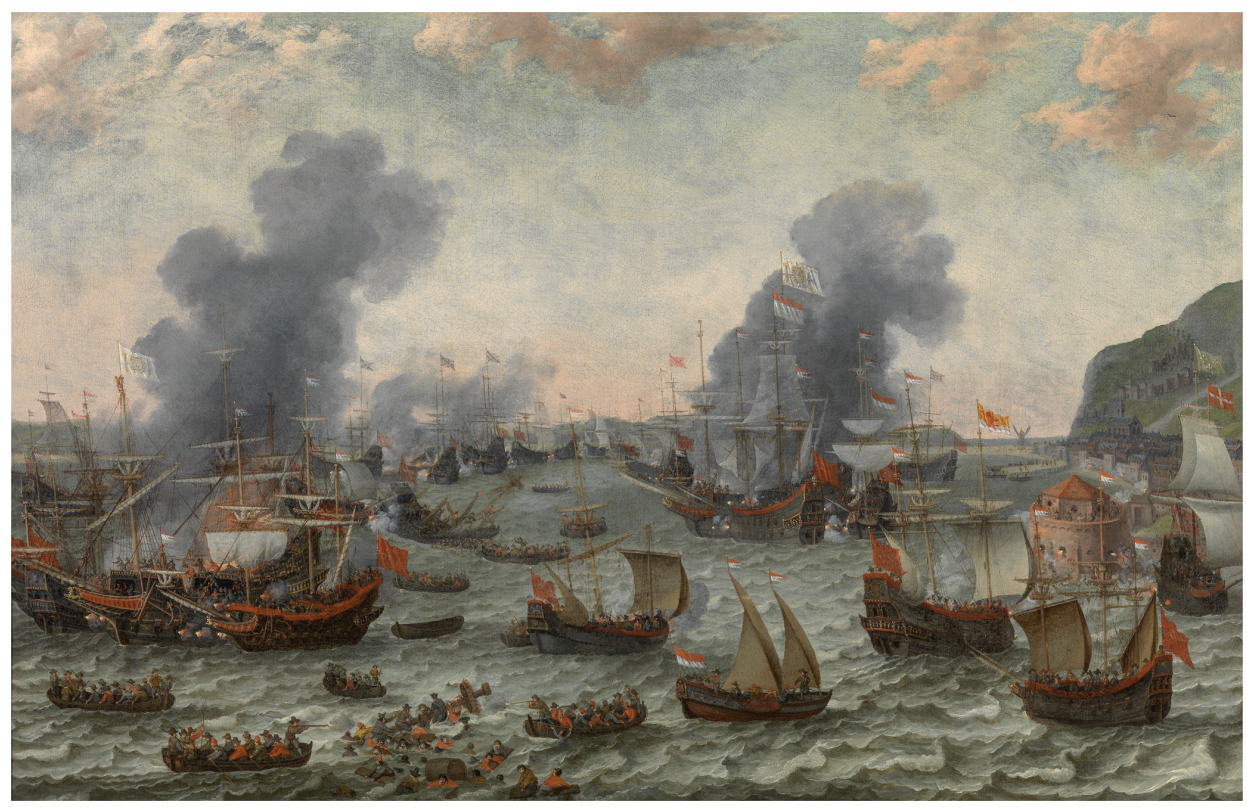

Fig. 13 Adam Willaerts, La Batalla de Gibraltar, 25 de abril 1607 (ca. 1617), oil on canvas, $78,3 \mathrm{~cm} \times 121,5 \mathrm{~cm}$, Madrid, Museo del Prado, Po7758.

smaller Burgundian cross on the far left, used in the fifteenth and early sixteenth centuries by the Habsburgs, is uppermost. Moreover, the exact same arrangement can be observed in a painting by Adam Willaerts of the Battle of Gibraltar (1607). The fleet is depicted in the distance, but a closer look reveals that the highest flag depicted is the Spanish flag with the royal standard, flanked by the two pillars of Hercules. ${ }^{87}$ Likewise, another piece by Willaerts of Gibraltar prominently shows the Spanish royal standard in the very centre of the painting and on top (fig. 13). ${ }^{88}$ The same can be said for the painting discussed above, in which the flagship the Royal James was portrayed in a humiliating posture: the English flag, though tarnished or blackened, is still uppermost, consistent with English precedence in international relations.

Because it would be unfeasible to check this hypothesis in all the maritime paintings from this period, I have used those in Het Scheepvaartmuseum in Amsterdam as a pilot sample. This is warranted because the museum holds a representative collection of Dutch seventeenth century maritime art. In a painting of a French and Dutch fleet locked in battle (1672) by Willem van de Velde, the blue French royal standard on the main mast is clearly the highest flag in the painting, confirming the precedence of the French crown over the 


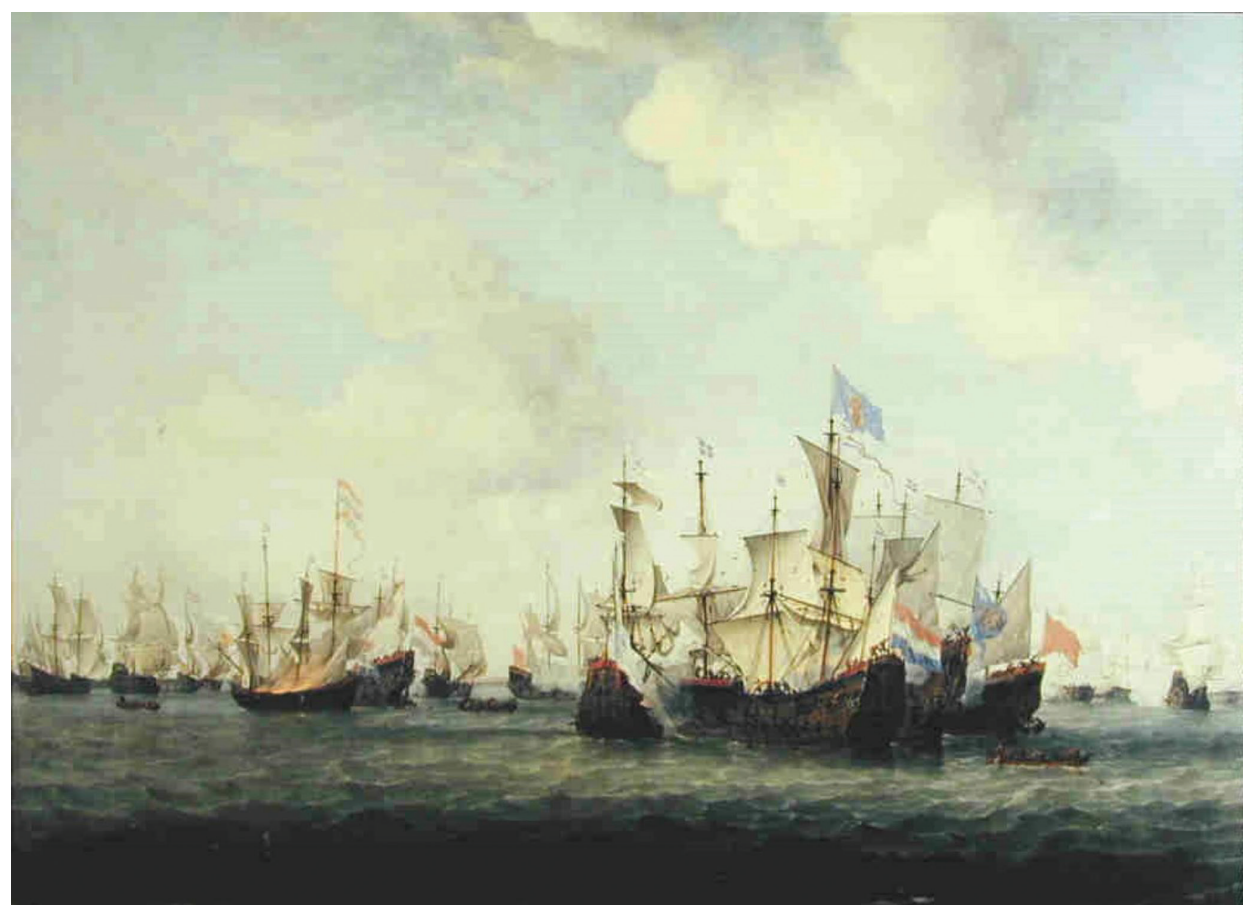

Fig. 14 Willem van de Velde II, Battle between Holland and French commercial ships (1672), oil on canvas, $85 \times$ 107,5 cm, Amsterdam, Het Scheepvaartmuseum, Amsterdam, B.0207(04).

Dutch Republic (fig. 14). ${ }^{89}$ In the Skirmish between Dutch and Turkish ships (1650) by Jeronymus van Diest, the Dutch flag is clearly higher, consistent with the notion that the Ottoman Empire was outside the European system..$^{\circ}$

However, there are also a few paintings in which the argument does not apply. The painting by Hendrick Vroom of the Battle of Sluis (1605) is a good example, in which the Dutch flag is flying way above all the Spanish flags. ${ }^{91}$ This seems to contradict the hypothesis. However, it must be noted that this specific painting shows a bird's eye perspective, which is unusual and makes it difficult to estimate height. Likewise, the Battle of Kijkduin, an episode in the Third Anglo-Dutch War (1673) by Willem van de Velde II, clearly shows the Dutch, rather than the English, flag highest. ${ }^{92}$

89 Willem van de Velde II, Scheepsgevecht tussen Hollandse en Franse koopvaardijschepen (1672), Amsterdam, Het Scheepvaartmuseum, B.0207(04); Allard, Nieuwe Hollandse Scheepsbouw, n.p., no. 52.

90 Jeronymus van Diest, Schermutseling tussen Hollandse en Turkse schepen (1650), Amsterdam, Het Scheepvaartmuseum, A.ooo1.

91 Vroom, De slag bij Sluis (see fig. 8).

92 Willem van de Velde II, De Zeeslag bij Kijkduin, 21 augustus 1673 (1687), Amsterdam, Het Scheepvaartmuseum, A.0291. 
There are also a number of paintings in which, strikingly, two flags are positioned at equal heights, close to each other and are approximately the same size. This would also support my hypothesis. For instance, two paintings of the Battle of the Sound (1658) by Peter van de Velde and by Jan Beerstraten show the Dutch and Swedish fleets locked in battle. ${ }^{93}$ What is striking about both paintings is that neither the Dutch nor Swedish flag is really uppermost in the painting; they seem to be on a par, even if in the first painting the Dutch flag seems to be slightly elevated above the Swedish one. This is not consistent with Allard's naval claim, but possibly in line with diplomatic reality. Whereas Sweden was a kingdom and therefore higher up in the international hierarchy, the Dutch Republic may have regarded itself as rather equal to this lesser kingdom, unlike that of England, Spain, or France. ${ }^{94}$ Again, it might seem coincidence, but the hypothesis gains credence by the very fact that two distinct painters of the Battle of the Sound agreed precisely on this particular flag arrangement.

What are we to conclude from this case study? Surely, we should not be looking for secret codes in paintings, but it seems fair to argue that artistic conventions and diplomatic practice could converge. Six out of twelve paintings of naval battles in Het Scheepvaartmuseum confirm the hypothesis of international hierarchy, whereas two do not. If we include the paintings in which flags are portrayed at the same height, ten out of twelve researched paintings confirm the hypothesis. Two paintings could not be used because the flags portrayed were too vague.

In order to further strengthen the hypothesis, I made a selection from the Rijkmuseum's vast collection of naval paintings, using the search term zeeslag (naval battle) and narrowing the results down to coloured paintings. Of the fifty paintings, twenty-three clearly show a naval battle scene (other search results point to portraits of commanders). Of these, thirteen paintings confirm the hypothesis of international hierarchy, four paintings are indistinct, and six paintings clearly contradict the hypothesis. ${ }^{95}$ A clear but in itself unconvincing

93 Peter van de Velde, Zeeslag in de Sont, 8 november 1658 (1670-1679), Amsterdam, Het Scheepvaartmuseum, RB.0324; Jan Abrahamsz. Beerstraten, De eerste fase van de Zeeslag in de Sont, 8 november 1658 (1660), Amsterdam, Het Scheepvaartmuseum, S.2063.

94 But see Allard, Nieuwe Hollandse Scheepsbouw, 9, which places England and Holland on top.

95 Confirming the hypothesis are: Cornelis Claesz. van Wieringen, Battle of Gibraltar 1607 (ca. 1620), SK-A2163 (Spanish flag on top); Willem van de Velde, Captured ships after the Four Days' Battle 1666 (ca. 1666), sK-A-439 (English flag on top); Reinier Nooms, Battle of Livorno 1653 (1653-1660), sK-A-294 (English flag on top); Willem van de Velde, Episode from the Four Days' Battle 1666 (ca. 1672), sK-A-1392, (English flag on top); Willem van de Velde, Surrender of the Royal Prince 1666 (1670), sK-C-1743 (English flag on top); Willem van de Velde, Battle of Solebay 1672 (1691), sK-A-1716 (English flag on top); Willem van de Velde, Capture of the Royal Prince 1666 (1670), sK-A-438 (English flag on top); Abraham Beerstraten, Battle of Foja 1649 (1656), SK-A-3737 (Venetian flag higher than Dutch); Jan Abraham Beerstraten, Battle of Terheide 1653 (1653-1660), SK-A-22 (English flag on top); Adam Willaerts, Battle of Gibraltar 1607 (1639), SK-A-2162 (Spanish flag on top); Adam Willaerts, Battle of Gibraltar 1607 (1617), sK-A-1387 (Spanish flag on top); Adam Willaerts, Allegory on the Battle of Gibraltar 1607 (1615-1630), sK-A-4116 (Spanish flag on top); Jan Theunis Blanckerhof, Battle of the Zuiderzee 1573 (1663), sK-A-3235 (Spanish flag on top). Against the hypothesis: Willem van de Velde, Battle of Kijkduin 1673 (ca. 1675), sk-A-2393 (Dutch flag on top); Peter van de Velde, Battle of Elsinor 1658 (1670-1679), SK-A-3271 (Dutch and Swedish flag seem on a par, Dutch flag slightly higher); Cornelis Bol, Encounter between Dutch and Spanish ships 1602 (1635-1650), sK-A-4250 (Dutch flag on top); Hendrick Vroom, Dutch ships crush Spanish ships 1602 (1617), sK-A-46o (Dutch flag on top); Abraham de Verwer, Battle of the Zuiderzee 1573 
majority (thirteen out of twenty-three) of the paintings thus confirm the hypothesis. Indeed, we must be careful to draw firm conclusions from such a small sample, and with a result that is still ambiguous. Moreover, there might be a bias in favour of the hypothesis: especially in the early seventeenth century, Spanish ships were usually larger than Dutch ships and would thus have higher masts. ${ }^{96}$ For the paintings this would only impact the results if the scenes are depicted from the side, but often they are shown from a slight bird's eye perspective. More importantly, we would have to know more about specific paintings before we can draw definite conclusions. When was the painting made? Who made it, and for whom? Does the specific historical scene lead us to draw further conclusions?

Van Wieringen's Gibraltar piece provides clear evidence that the matters of timing and patronage are important clues to understanding the painting. It also underscores that the imagery of flags and coats of arms were not random but consciously selected. The painting was commissioned in 1621, the year in which the Twelve Years' Truce with Spain lapsed and hostilities resumed. Undoubtedly, the painting was a reminder of one of the most glorious victories the Dutch had achieved, and was intended to inspire and boost morale. Moreover, the painting was a present by the Admiralty to Prince Maurice of Nassau, stadtholder and leader of the war party. Whereas a number of scenes in the painting correspond with contemporary journals and records, the ship that was painted right at the centre of the painting was simply never there. ${ }^{97}$ It bears the flag of Amsterdam and the coat of arms of Maurice of Nassau. It may be interpreted as an acknowledgment of the fact that Maurice was the admiral-general, but arguably the unusual inclusion of his heraldic signature lends the painting ideological force. Unlike his opponents, the stadtholder was in favour of resuming the war. The coat of arms included the Order of the Garter, which he had received in 1612 . The painting therefore represents the situation of 1621 , rather than the one in 1607. Incidentally, in August 1621 there was another battle off Gibraltar in which the Dutch fleet was defeated. In a real sense, therefore, this painting in a way refers to the 1621 battle as well, trying to bolster Dutch morale.

If patronage and timing are important clues, so is authorship. The majority of paintings studied in this article support the hypothesis, but there were also significant exceptions. However, the numbers change dramatically if we make a selection based on artists. If we look, for instance, at the selection of paintings from the Rijksmuseum, and we limit our analysis to specific painters, the result is very different. The painters Adam Willaerts, Willem van de Velde II, Cornelis Claesz. van Wieringen, and Jan Beerstraten consistently confirm the hypothesis (thirteen out of fourteen paintings), whereas a painter like Hendrick Vroom does not show any consistency.

(1621), sK-A-603 (Dutch flag prominently on top); Hendrik van Anthonissen, Surprise attack on Portuguese ships 1639 (1653), sK-A-2126 (Dutch flag on top). Indistinct are: Anonymous, Battle near Livorno 1653 (1653-1660), no cat. no. (indistinct: only Dutch flag visible); Anonymous, Battle of Vigo 1702 (ca. 1705) SK-A-1947 (indistinct, only Dutch flag visible); Simon de Vlieger, Battle of the Slaak 1631 (1633), SK-A-454 (Spanish and Dutch flag on a par, Dutch flag appears higher); Hendrick Vroom, Battle of the Haarlemmermeer 1573 (ca. 1629), sK-A-602 (indistinct, Spanish flag appears higher).

96 I thank Joost Schokkenbroek for this observation.

97 A detailed analysis of the painting is in Voorbeijtel, 'De zeeslag bij Gibraltar', and Daalder, 'Cornelis Claesz. van Wieringen'. 
A final distinctive clue is related to the actual content of the painting. That is, would the specific scene that the painter represents lead us to speculate on an ideological motive? There is, of course, the possibility that the paintings were even more sophisticated than meets the eye. If we look at Van de Velde II's only painting in the Rijksmuseum that contradicts the hypothesis, the depiction of the Battle of Kijkduin, we see that the Dutch flag, unusually for Van de Velde, is higher than the English flag. Again, this might be coincidence, but we know that Van de Velde was politically conscious and was used to working for the Admiralty and also for the King of England. On closer inspection, the painting deviates from the other paintings in one respect, which might account for its exception. The scene depicted is from the Third Anglo-Dutch War, and represents the Battle of Kijkduin (1673), near Den Helder just off the Dutch coast. That would put the scene, as opposed to all the other paintings, squarely in Dutch waters. Even if the notion of territorial waters was not established during this period, the Dutch would have recognized this as their home turf. Indeed, in 1671 the States-General had precisely claimed sovereignty in their own territorial waters, refusing to give in to English demands to salute their ships. ${ }^{98}$ This might explain why another painting by Van de Velde II in the Rijksmuseum, which is not included in this survey, also depicting the Battle of Kijkduin, again shows a Dutch flag higher. ${ }^{99}$ In short, Van de Velde consistently acknowledged English superiority unless in Dutch waters.

Keeping these distinctive features in mind, what are the results if we focus on specific artists? Referring to Willem van de Velde the Younger, Michael S. Robinson, former Keeper of the Pictures in the Greenwich-based National Maritime Museum, speaks of his 'usual accuracy in the matter of flag', making his work suitable for a case study. ${ }^{100}$ This final section therefore contains a thorough analysis of the works of Van de Velde, based on the extensive catalogue compiled by Robinson for the National Maritime Museum in Greenwich in 1991. ${ }^{101}$ Robinson lists 72 paintings by Van de Velde II, or on some occasions of his father (Van de Velde I), of naval battles. The majority of these were created between 1653 and around 1700, and depict scenes from the three Anglo-Dutch Wars (1652-1654, 16651667, and 1672-1674), the Nine Years' War (1688-1697), and various scattered incidents with Barbary corsairs in the Mediterranean. Thirteen of these paintings cannot be analysed because no reproductions are available, mainly because they are held in private collections (appendix 1). Eight more paintings were not included in the analysis because the flag arrangements are impossible to distinguish, mainly because they depict a naval battle between fleets that that takes place in the far distance (appendix 2). Two paintings were not actually by Van de Velde $\mathrm{I}$ or Van de Velde $\mathrm{II} .{ }^{102}$ One painting is not depicting a battle,

\footnotetext{
98 Groot Placaet-Boeck, 52.

99 Willem van de Velde II, Encounter during the Battle of Kijkduin (ca. 1675), Amsterdam, Rijksmuseum, SK-A-2393.

100 Robinson, Van de Velde, I, 243.

101 Robinson, Van de Velde. I owe this reference to Judith Noorman. The paintings in the following notes and appendices have been given a code starting with MSR, which refers to the catalogue number given by Robinson. Where possible I have added the date of creation, dimensions of the painting, and current location.

102 The Burning of the Soleil Royal at the Battle of La Hogue, 23 May 1692 ('in the style of Van de Velde', $101,5 \times 124,5 \mathrm{~cm}$, National Maritime Museum BHC0335, MSR 714); An English two-decker attacking a Barbary port (by Jacob Knijff, $99 \times 137$ cm, National Maritime Museum BHC0321, MSR 320).
} 


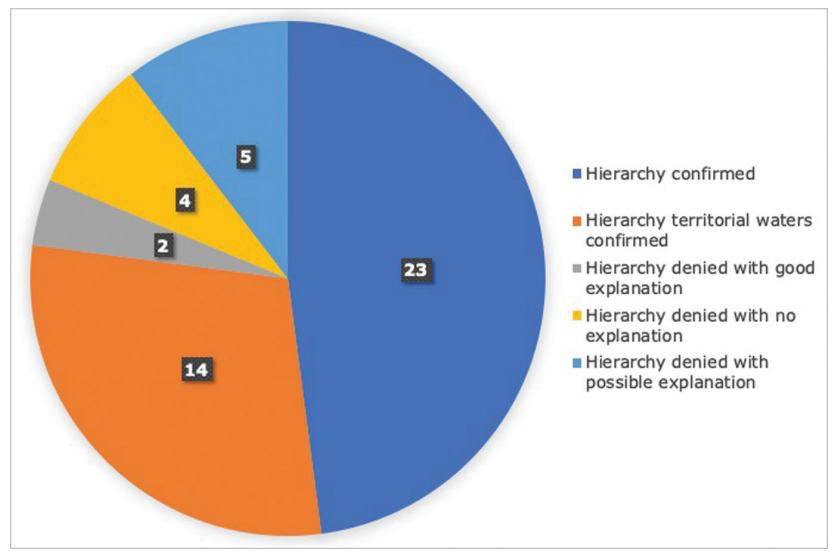

Fig. 15 Number of paintings by the Willem van de Velde $I$ and II either confirming or contradicting the hypothesis concerning the international hierarchy in flag arrangements.

but the destruction of a Dutch merchant fleet by English warships. ${ }^{103}$ This leaves us with a corpus of forty-eight paintings. Of these, thirty-seven paintings confirm the hypothesis (appendix 3), whereas eleven do not (appendix 4). An overwhelming majority of more than three in four paintings thus confirm the hypothesis. Moreover, of these eleven paintings that do not confirm the thesis, there is no explanation for four, but a good explanation for two and a possible explanation for five paintings. The distribution is visualised in the chart above (fig. 15).

If we look first at the paintings that confirm the hypothesis, two categories can be distinguished. The first category are twenty-three paintings in which the international hierarchy is confirmed. ${ }^{104}$ An example is The towing away of the Royal James, now in Het Scheepvaartmuseum in Amsterdam. ${ }^{105}$ It depicts a scene in the Second Anglo-Dutch War in which, even though the Royal James has a broken mast and has surrendered, its flag is obviously highest on the painting. Another example is The 'Mary Rose' Action, 28 December 1669, showing an English fleet fighting off Barbary corsairs in the Mediterranean. ${ }^{106}$ The fourteen paintings in the second category consistently confirm hierarchy in the sense that the territorial waters (that is: in sight of the coast) are acknowledged. ${ }^{107}$ Thus, a scene in 1667 showing an English fleet attacking a French fleet in the port of the Caribbean colony of Martinique clearly shows the French flags in top. ${ }^{108}$ Finally, a painting showing an English fleet attacking the Algerian port of Béjaïa clearly shows a red flag with a crescent

103 'Holmes's Bonfire', the burning of Dutch Merchant Ships between Terschelling and Vlieland, 19th August $1666(125,7 \times 181,6 \mathrm{~cm}$, Royal Collection Trust RCIN 406560, MSR 44).

104 MSR 390, 424-2, 424-3, 75, 109, 136, 118, 37, 108, 267, 427, 630, 71, 43-1, 626, 318, 319, 629, 472, 470, 43-2, $117,114$.

105 MSR 118.

106 MSR 37.

107 MSR 424-4, 425, 41, 40, 38, 38-2, 38-3, 315, 403, 421, 631, 633, 26, 39.

108 MSR 41. 
in top -on open sea, in contrast, most paintings representing battles between corsairs and European ships would have the European flags in top. ${ }^{109}$

Whereas thirty-seven paintings thus confirm the thesis, eleven do not. For the purpose of this article I have divided these into three categories: for four paintings, I have no explanation as to why they do not confirm the thesis. In two cases there is a very specific reason as to why they do not confirm, and for five paintings a reasonable explanation might suffice. In the first category of four paintings is the Episode from the Four Days' Battle, now in Museum Gijn in Dordrecht, depicting a scene from the Second-Anglo Dutch War, showing the Dutch flag in top and thus rejecting international hierarchy. Robinson notes several mistakes in the flag configuration in this painting, and also remarks that it was probably commissioned by a Dutch captain. Even so, these points do not serve to explain why the Dutch flag is in top. ${ }^{110}$ In the second category are two paintings of the Third Anglo-Dutch War showing The burning of the Royal James at the Battle of Solebay (1672), with Dutch flags in top. ${ }^{11}$ While these contradict the hypothesis, Robinson remarks that the proportions and distances are deliberately inflated so that the Dutch ship in the foreground is too large. According to Robinson, this is probably because these paintings were commissioned by a Dutchman. Other depictions of the same scene clearly show the English flag in top. Of one of those there are nine known versions, underscoring the suggestion that the two paintings mentioned above are exceptional. ${ }^{12}$ In the final category are five paintings that do not confirm with international hierarchy, but for which a reasonable explanation can be found. ${ }^{113}$ The first one is The Burning of the Andrew at the Battle of Scheveningen, a scene from the First Anglo-Dutch War in $1653 .{ }^{114}$ The English flag is in top, confirming international hierarchy, but contradicting my argument that this did not apply in territorial waters. This is, however, Van de Velde II's very first naval battle painting, and stems from a time in which the conflict about territorial waters was not yet out in the open (it really became an issue under Charles II after 1660). Two further paintings show the Dutch flag in top where it should not be, but in these cases the actual battle scene is in the far distance, whereas the actual scene of the painting is one specific fleet, for instance in The Hollandia disabled after a collision with the Liefde. ${ }^{115}$ In one case patronage might have played a role. ${ }^{116}$ The final painting has an English flag on top where it should not, but it is actually a signal flag rather than an identity flag. ${ }^{117}$

Whereas the vast majority of the paintings thus confirm the thesis, a number of paintings clearly do not. Focusing on patronage or the year of production frequently provides clues as to why this could be the case. What may be reasonably deduced from this short case-study, however, is not that flag arrangements on paintings are an exact science. Rather, it shows that paintings from the Van de Veldes, who were known to be accurate in

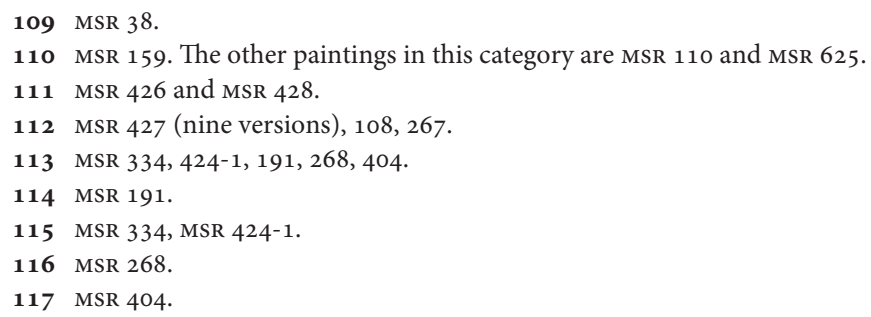


representing flag arrangements, show unmistakable patterns that are aligned with contemporary notions of international hierarchy and territorial waters.

\section{Conclusion}

The purpose of this article was to investigate flags on Dutch paintings of naval battle scenes as lenses on early modern identities, being a case-study in New Diplomatic History. It has shown that there is a vexillological iconography typical for marine painting, which is apparent from a series of motifs or patterns. Whereas it is clear that at one level these paintings could be fairly faithful representations of an actual event, at another level they communicated a political and ideological message. They were, in Goedde's words, an 'imaginative re-creation of the battle'. The case studies in this article have demonstrated the validity of this claim. Van Wieringen's Battle of Gibraltar has shown the symbolic significance of the portrayal of flags. Tarnished flags were used symbolically, conveying a political or religious message, celebrating victory or remembering fallen heroes. I have also suggested more complex patterns, in which the configuration of flags points to multiple layers of national, provincial, municipal, or religious identity. Lastly, it appears that the selection, portrayal, and positioning of flags on paintings was deliberate and had ideological and as such were engaging in the negotiation of international hierarchy.

In conclusion, then, flags in marine paintings are markers that represent contemporary views on the complex political world of the early modern age. It is worthwhile considering the possibilities of extending the field of historical vexillology. There are, for instance, plenty of flags on maps in the early modern age, which probably also carry ideological meaning. ${ }^{118}$ Moreover, the depiction of flags in paintings of land battles merits further attention. Some preliminary research by the author of this article has suggested that the representation of flags on paintings of land battles was quite different from that of sea battles, but firm conclusions await systematic research. Arguably, the field of historical vexillology promises to be rewarding.

\section{Appendix 1. Naval battles painted by Willem van de Velde II for which no reproduction is available.}

1. The Battle of Lowestoft $(1665,134,5 \times 216 \mathrm{~cm}$, Collection of the Marquess of Bute, MSR 74).

2. The Four Days' Battle (Collection of the Early of Derby, MsR 424).

3. The Four Days' Battle (ca. 1672, 33,7 ×42,5 cm, Collection of the Duke of Sutherland, 765).

4. The Four Days'Battle $(35,2 \times 45,3$ cm, Institut Néerlandais, Paris, MSR 161).

5. The burning of the Royal James at the Battle of Solebay (Rupert Preston London, MSR 429).

6. Battle of Kijkduin (Spink and Son, MSR 422). 
7. The Burning of the Soleil Royal at the Battle of La Hogue, 23 May $1692(78,7 \times 120,5 \mathrm{~cm}$, Unknown collection, MSR 634).

8. The Burning of the Soleil Royal at the Battle of La Hogue, 23 May 1692 (Collection of Lord Sandys, MSR 635).

9. A battle between the English and French, probably Barfleur 29 May 1692 (1692, $91,5 \times 127 \mathrm{~cm}$, Carlton Galleries, London, MSR 632).

10. An action between an English ship and Barbary ships $(54,5 \times 74,9 \mathrm{~cm}$, Collection of Lord Chelwood, MsR 627).

11. An action between a Portuguese ship and a number of Barbary galleys and a ship $(31,5 \times 47,5 \mathrm{~cm}$, Gallerie de Jonckheere, Brussels, MSR 747).

12. An action between galleys and ships $(26,7 \times 36,9 \mathrm{~cm}$, MSR 628$)$.

13. An engagement of English and Dutch ships with Barbary galleys $(34,2 \times 50,5 \mathrm{~cm}$, Niedersächsischen Landesgallerie, Hanover, MSR 124).

Appendix 2. Naval battles painted by Willem van de Velde II in which the flag arrangements cannot be distinguished.

1. Battle of Solebay $(127 \times 185,5 \mathrm{~cm}$, National Maritime Museum, MSR 312).

2. First Battle of Schooneveld (National Maritime Museum, MsR 313).

3. Battle of Kijkduin (series of 6 paintings, National Maritime Museum, MSR 423).

4. An English ship in action perhaps with Barbary ships at night $(31,5 \times 62,3 \mathrm{~cm}$, Collection of Fritz von Gans, MSR 639).

5. Battle of Texel $(1682,126 \times 182,5 \mathrm{~cm}$, Royal Collection Trust, MSR 45).

6. Battle of Texel (ca. 1674, Collection at Felbrigh Hall, MSR 143).

7. An action between an English and a Barbary boat with ships and galleys engaged $(32 \times 49 \mathrm{~cm}$, Yale Center for British Art, MSR 14).

8. An action between ships and Barbary galleys $(40,5 \times 67.2 \mathrm{~cm}$, Copenhagen Statens Museum for Kunst, MSR 128).

Appendix 3. Naval battles painted by Willem van de Velde II confirming the hypothesis.

1. Battle of Kijkduin (late $17^{\mathrm{TH}}$ century, $114,3 \times 185,5$, National Maritime Museum, MSR 403).

2. The Battle of Barfleur (1692, Collection of the Duke of Grafton, MSR 631).

3. The End of the Action between the English Indiaman and Three Spanish Privateers (1682, 142,5 × 199,2 cm, Royal Collection Trust, MSR 43-2).

4. Naval battle between Dutch and French merchant ships $(85 \times 107,5 \mathrm{~cm}$, Het Scheepvaartmuseum, MSR 117).

5. The Attack on Shipping in Tripoli, 24th January 1676 (ca. $1676,126,2 \times 182,8$, Royal Collection Trust, MSR 39). 
6. The Dutch ships Huis Tijdverdrijf and Edam ashore and burning a Barbary ship near Tetuan (96,8 $\times 125 \mathrm{~cm}$, Collection of the Marquess of Cholmondeley, MSR 390).

7. The Royal Prince pursued by the Dutch fleet (ca. $1690,70 \times 119 \mathrm{~cm}$, Collection of the Earl of Derby, MSR 424-2).

8. The surrender of the Royal Prince on the third day (ca. 1690, 70,5 $\times 118,5$, Collection of the Earl of Derby, MSR 424-3).

9. The Four Days' Battle (ca. $1673,75,3 \times 106,3 \mathrm{~cm}$, Collection of the Duke of Sutherland, MSR 75).

10. The capture of the Royal Prince (ca. $1670,58,5 \times 81 \mathrm{~cm}$, Rijksmuseum, MSR 109).

11. The Four Days' Battle ( $18^{\mathrm{TH}}$ century, $42 \times 52 \mathrm{~cm}$, Mauritshuis, MSR 136$)$.

12. The towing away of the Royal James (ca. $1675,148 \times 185 \mathrm{~cm}$, Het Scheepvaartmuseum, MSR 118).

13. The 'Mary Rose' Action, 28 December $1669(1676,126,4 \times 182,9$ cm, Royal Trust Collection, MSR 37).

14. Battle of Solebay $(1691,112 \times 182 \mathrm{~cm}$, Rijksmuseum, MSR 108).

15. The burning of the Royal James at the Battle of Solebay (ca. 1680, $104 \times 153,5 \mathrm{~cm}$, National Maritime Museum, MSR 267).

16. The burning of the Royal James at the Battle of Solebay $(1676,89 \times 94 \mathrm{~cm}$, Het Scheepvaartmuseum, MSR 427).

17. The Battle of Bantry Bay (possibly by Van Diest, late $17^{\mathrm{TH}}$ century, $94 \times 137 \mathrm{~cm}$, National Maritime Museum, MSR 630).

18. A battle of the Third Anglo-Dutch War $(110,5 \times 137 \mathrm{~cm}$, Estate of James Christie, MSR 71).

19. An English Indiaman attacked by three Spanish privateers (c. $1675,126,3 \times 182,8$, Royal Collection Trust, MsR 43-1).

20. An action between an English ship and Barbary ships and galleys $(32,5 \times 83,8 \mathrm{~cm}$, Ham House, MSR 626).

21. An English ship in action with Barbary vessels $(102,7 \times 147 \mathrm{~cm}$, National Maritime Museum, MSR 318).

22. An English ship in action with Barbary ships $(110,5 \times 197 \mathrm{~cm}$, National Maritime Museum, MSR 319).

23. An action between an English ship and Barbary ships and galleys ( $30 \times 50 \mathrm{~cm}$, MSR 629).

24. An English ship under a press of sail coming up with a French ship in moderate breeze $(52,8 \times 87.6 \mathrm{~cm}$, Collection of Sir Bruce Ingram, MSR 472).

25. An English ship under a press of sail coming up with a French ship in moderate breeze $(63,5 \times 96,5 \mathrm{~cm}$, Collection of the Earl of Warwick, MSR 470).

26. Dutch ships with their prizes returning to Goeree after the battle $(70,2 \times 119,2 \mathrm{~cm}$, Collection of the Earl of Derby, MSR 424-4).

27. Dutch ships returning with their prizes to Goeree after the Four Days Battle, 4 June 1666 (late $17^{\mathrm{TH}}$ century, $64 \times 95 \mathrm{~cm}$, National Maritime Museum, MSR 425).

28. The Attack on the French Ships at Martinique, 6th July 1667 (1675, Royal Collection Trust, MSR 41).

29. The destroying of six Barbary ships near Cape Spartel $(1677,126 \times 182,9 \mathrm{~cm}$, Royal Collection Trust, MSR 40). 
30. The Attack on Shipping in Bugia, 18 May $1671(1677,125,7 \times 182,9 \mathrm{~cm}$, Royal Collection Trust, MSR 38).

31. The Attack on Shipping in Bugia, 18 May $1671(1675,129,5 \times 182,9 \mathrm{~cm}$, Royal Collection Trust, MSR 38-2).

32. The Attack on Shipping in Bugia, 18 May 1671 (1675, 125,3 $\times 182,6 \mathrm{~cm}$, Royal Collection Trust, MSR 38-3).

33. Battle of Kijkduin $(1687,150 \times 300 \mathrm{~cm}$, Het Scheepvaartmuseum, MSR 315).

34. Battle of Kijkduin (late $17^{\mathrm{TH}}$ century/early $18^{\mathrm{TH}}$ century, $81,3 \times 144,8$, National Maritime Museum, MSR 421).

35. The Burning of the Soleil Royal at the Battle of La Hogue, 23 May 1692 (late $17^{\mathrm{TH}}$ century, $62 \times 76 \mathrm{~cm}$, National Maritime Museum, MSR 633).

36. The Dutch ship Gouden Leeuw engaged withan English flagship in a fleet action (ca. $1686,57,1 \times 73,7 \mathrm{~cm}$, Davis Museum and Cultural Center, MSR 26).

37. Episode from the The Four Days' Battle $(1666-1672,151 \times 235$ cm, Rijkmuseum, MSR 114)

Appendix 4. Naval battles painted by Willem van de Velde II contradicting the hypothesis.

1. The Burning of the Andrew at the Battle of Scheveningen (ca. 1653,84,6×108,1 cm, Wallace Collection, MSR 191).

2. Episode from the Four Days' Battle $(1690,96,5 \times 149 \mathrm{~cm}$, Huis van Gijn, Dordrecht, MSR 159).

3. Captured English ships after The Four Days' Battle $(1666,58 \times 81 \mathrm{~cm}$, Rijkmuseum, MSR 110).

4. An action between an English ship and Barbary ships $(62,2 \times 90,2 \mathrm{~cm}$, Collection of the Earl of Middleton, MSR 625).

5. The burning of the Royal James at the Battle of Solebay $(1690,105 \times 179,5 \mathrm{~cm}$, Private collection, MSR 268).

6. The burning of the Royal James at the Battle of Solebay $(1700,57 \times 85 \mathrm{~cm}$, Private collection, MSR 426).

7. The burning of the Royal James at the Battle of Solebay $(30 \times 45 \mathrm{~cm}$, Government Art Collection British Embassy The Hague, MSR 428).

8. Battle of Kijkduin $(81 \times 145 \mathrm{~cm}$, National Maritime Museum, MSR 404).

9. The action at Bergen $(62,2 \times 114,3 \mathrm{~cm}$, National Maritime Museum, MSR 334$)$.

10. The Hollandia disabled after a collision with the Liefde (ca. 1690, 70 $\times 119 \mathrm{~cm}$, Collection of the Earl of Derby, MSR 424-1).

11. The Action of the Kingfisher with Seven Algerine Ships, 1 June $1681(1683,126 \times 182,5$ $\mathrm{cm}$, Royal Collection Trust, MSR 42).

\section{Bibliography}

Aalbers, Johan, De Republiek en de vrede van Europa. De buitenlandse politiek van de Republiek der Verenigde Nederlanden na de vrede van Utrecht (1713), voornamelijk gedurende de jaren 1720-1733 (Groningen 1980). 
Allard, Carel, Nieuwe Hollandse Scheepsbouw (Amsterdam: Carel Allard 1695).

Admiralty of Amsterdam letters, Nationaal Archief, The Hague, 1.01.46-1536.

Balbian Verster, J.F.L., 'De slag van Gibraltar door Vroom', Jaarverslag Scheepvaartmuseum Amsterdam 6 (1922) 47-56.

Bender, James, Dutch Warships in the Age of Sail 1600-1714. Design, Construction, Careers and Fates (Barnsley 2014).

Beylen, Jules van, 'Schepen op kaarten ten tijde van Gerard Mercator', Duisburger Forschungen 6 (1962), 131-157.

Beylen, Jules van, 'Scheepstypen', in L.M. Akveld et al. (eds.), Maritieme geschiedenis der Nederlanden, 4 vols (Bussum 1976-1978) II, 11-71.

Blackmore, David, Warfare on the Mediterranean in the Age of Sail. A History, 1571-1866 (London 2011).

Brand, Ron, "'Een schilderije van de Slach van Heemskerck”. Cornelis Claesz. van Wieringen en de opdracht voor een zeestuk van de slag bij Gibraltar nader bekeken', Tijdschrift voor Zeegeschiedenis 34 (2015/2) 3-22.

Brand, Ron, 'Vlagvertoon aan het Spaarne. Het gebruik van vlaggen door Hendrick Cornelisz. Vroom en Cornelis Claesz. van Wieringen op hun zeestukken', Desipientia 23 (2016/2) 6-11.

Cockett, Frank B., Early Sea Painters 1660-173o (Woodbridge 1995).

Daalder, Remmelt, 'Cornelis Claesz. van Wieringen en de Zeeslag bij Gibraltar in 1607', Scheepshistorie 9 (2010) 48-53.

Daalder, Remmelt, 'Een zeeslag voor prins Maurits', Amstelodamum 95 (2008/2) 3-12.

Daalder, Remmelt, 'Modello voor een schilderij van de Zeeslag bij Gibraltar, 25 april 1607', in Jeroen Giltaij and Jan Kelch (eds.), Lof der Zeevaart. De Hollandse zeeschilders van de $17^{\mathrm{E}}$ eeuw (Rotterdam and Berlin 1996), 20-23.

Daalder, Remmelt, 'Schermutseling in het Kanaal', in E. Spits (ed.), Het Scheepvaartmuseum. Verhalen over de zee in 100 Iconen (Zwolle 2013).

Daalder, Remmelt, Van de Velde en zoon, zeeschilders. Het bedrijf van Willem van de Velde de Oude en Willem van de Velde de Jonge, 1640-1707 (Leiden 2015).

Davies, David, Kings of the Sea. Charles II, James II and the Royal Navy (Havertown 2017).

Davies, David, 'The birth of the imperial navy? Aspects of maritime strategy c. 1650-1690', in Michael Duffy (ed.), Parameters of British naval power 1650-1850 (Exeter 1992) 14-38.

Ebben, Maurits, and Louis Sicking, 'Nieuwe diplomatieke geschiedenis van de premoderne tijd. Een inleiding', Tijdschrift voor Geschiedenis 127 (2014/4) 541-552.

Fulton, T.W., The Sovereignty of the Sea. An Historical Account of the Claims of England to the Dominion of the British Seas, and the Evolution of the Territorial Waters (Edinburgh and London 1911).

Geevers, Liesbeth, 'The diplomatic battle over precedence between France and Spain by way of arguments, 1564-1610', Tijdschrift voor Geschiedenis 127 (2014/4) 624-640.

Goedde, Lawrence O., 'Het zeestuk als historie en metafoor', in Jeroen Giltaij and Jan Kelch (eds.), Lof der Zeevaart. De Hollandse zeeschilders van de $17^{\mathrm{E}}$ eeuw (Rotterdam and Berlin 1996) 152-180.

Goedde, Lawrence O., Tempest and shipwreck in Dutch and Flemish art. Convention, rhetoric, and interpretation (University Park and London 1989).

Groot Placaet-Boeck Inhoudende de Placaten ende Ordonnantien van de Hoog. Mog. Heeren Staten Generael der Vereenigde Nederlanden ende vande Ed. Groot. Mog. Heeren Staten van Hollandt ende WestVrieselandt, Mitsgaders vande Ed. Mog. Heeren Staten van Zeelandt (The Hague: Jacobus Scheltus, 1683).

Heimer, Željko, Exploring Vexillology through Military Unit Flags (Zagreb 2016).

His Majesties Declaration against the States Generall of the United Provinces of the Low Countries (Edinburgh: Evan Tyler, 1672).

Holt, Mack P., 'Putting Religion Back into the Wars of Religion', French Historical Studies 18 (1993/2) 524-551.

Hulme, F.E., The flags of the world. Their history, blazonry, and associations (London 1897).

Jensen, Lotte (ed.) The Roots of Nationalism. National Identity Formation in Early Modern Europe, 1600-1815 (Amsterdam 2016). 
Jongh, Eddie de, Questions of meaning. Theme and motif in Dutch seventeenth century painting (Leiden 2000).

Le Neptune François, ou Atlas nouveau des cartes marines. Levées et gravées par ordre exprès du Roy. Pour l'usage de ses armées de mer (Paris: Hubert Jaillot, 1693).

Marvin, Carolyn, and David Ingle, Blood Sacrifice and the Nation. Totem Rituals and the American Flag (Cambridge 2011).

McCabe, Robert E., 'Flags', in John Hattendorf (ed.), The Oxford Encyclopedia of Maritime History, 4 vols. (Oxford 2007) II, 45-50.

Riley, Alexander, 'Flags, Totem Bodies, and the Meanings of 9/11. A Durkheimian Tour of a September 11 th Ceremony at the Flight 93 Chapel', Canadian Journal of Sociology/Cahiers Canadiens de Sociologie $39(2014 / 4) 719-740$.

Robinson, M.S., Van de Velde. A catalogue of the paintings of the Elder and the Younger Willem van de Velde, 2 vols. (Greenwich 1990).

Rommelse, Gijs, 'Het vernederen van een vlag', Zeemagazijn 43 (2016/3) 6-7.

Rommelse, Gijs, 'National flags as essential elements of Dutch naval ideology, 1600-180o', in David Davies et al. (eds), Ideologies of Western naval power, c. 1500-1815 (New York/Abingdon 2020), 33-52.

Russell, Margarita, Visions of the sea. Hendrick C. Vroom and the origins of Dutch Marine painting (Leiden 1983).

Schama, Simon, The Embarrassment of Riches. An Interpretation of Dutch Culture in the Golden Age (London 1991).

Scheurleer, D.F. (ed.), Van varen en van vechten. Verzen van tijdgenooten op onze zeehelden en zeeslagen. Lof-en schimpdichten, matrozenliederen, 3 vols. (The Hague 1914).

Schmidt, Benjamin, 'Mapping an Empire. Cartographic and Colonial Rivalry in Seventeenth-Century Dutch and English North America, The William and Mary Quarterly 54 (1997/3) 549-578.

Sharpe, Kevin, Rebranding Rule. The Restoration and Revolution Monarchy 1660-1714 (New Haven and London 2013).

Sigmond, Peter, and Wouter Kloek, Hollands Glorie. Zeeslagen in de Gouden Eeuw (Zwolle 2014).

Smith, Whitney, Flags through the ages and across the world (Maidenhead 1975).

Smith, Whitney, "What is the definition of "flag"? And 17 other vexillological questions posed to the Flag Research Center', Flag Bulletin 185 (1999) 3-39.

Spilbergen, Joris van, Copye van een brief, geschreven door Joris van Spelbergh (s.1. 1607)

Tarver, Michael, The Spanish Empire. A Historical Encyclopedia (Santa Barbara 2016).

Taylor, James, Marine painting. Images of sail, sea and shore (London 1995).

Tebel, Rene, Das Schiff im Kartenbild des Mittelalters und der Frühen Neuzeit. Kartographische Zeugnisse aus sieben Jahrhunderten als maritimhistorische Bildquellen (Wiefelstede 2012).

Trexler, Richard C., 'Follow the flag. The Ciompi revolt seen from the street', in Richard C. Trexler, The workers from Renaissance Florence. Power and dependence in Renaissance Florence, 3 vols. (New York 1993) III, 30-60.

Voorbeijtel Cannenburgh, Willem, 'De zeeslag bij Gibraltar', Twaalfde Jaarverslag 1928. Vereeniging Nederlandsch Historisch Scheepvaart Museum (Amsterdam 1928), 52-60

Watkins, John, 'Toward a new diplomatic history of Medieval and Early Modern Europe', Journal of medieval and early modern studies 38 (2008) 1-14.

Wilson, Timothy, Flags at sea (London 1986).

Witsen, Nicolaes, Aaloude en hedendaagsche scheepsbouw (Amsterdam: Pieter and Joan Blaeu, 1690). 